\title{
Global Constitutionalism and the Constitutionalization of International Relations: A Reflection of Asian Approaches to International Law
}

\author{
Surendra BHANDARI *
}

\begin{abstract}
With the emergence of global constitutionalism, domestic laws, policies, and administrative practices are demanded to be compatible with international laws. International laws are progressively assuming the position of supremacy over domestic laws like a constitution. State Parties are not free to eschew their obligations from giving effect to international laws. These minimum requirements of harmonization, supremacy, and authority of international law are constitutionalizing international relations, which has, indeed, already garnered the requisite legitimacy. In this regard, one of the obligations as well as contributions of Asia can be attributed to its participation in strengthening the practice of the constitutionalization of international relations. Against this background, this paper examines the nature of the constitutionalism of international law in defining and regulating international relations in reference to the idea of Asian approaches to international law. The query of what role has Asia played in history and what role is it playing in modern times in designing and practicing the concept of global constitutionalism might draw different paradigmatic responses, ranging from a passive recipient to an active partner and a designer of global constitutionalism. Since Asia itself is a vast region with heterogeneous genres of thought and varied levels of development, its role may well fit into all these paradigms with conceivable peculiarities among its members. This paper contends that any claim to modern international law as being a product of a single culture or tradition grossly undermines the history of international law and the existence of customary practices in different countries across the globe who have played innumerable roles in shaping modern
\end{abstract}

* Associate Professor, College of International Relations, Ritsumeikan University, Kyoto, JAPAN. The earlier version of this paper was presented and discussed in the Foundation for Development of International Law in Asia (DILA) Meeting 2013 organized in Indonesia. The author would like to thank Professor Kevin Tan, Professor Seokwoo Lee, Professor Paekeun Park, and all commentators, discussants, and participants for their valuable suggestions and feedback.

(C) The International Studies Association of Ritsumeikan University: Ritsumeikan Annual Review of International Studies, 2013. ISSN 1347-8214. Vol.12, pp. 1-53 
international law in terms of its foundational concepts. The analysis and arguments of this paper are divided into seven sections. The first section discusses the controversy of whether the origin of international law is attributable only to a Eurocentric explanation. The second section analyzes the relevance, if any, of a spatially fragmented concept like an Asian approach to international law. The third section analyzes the basic features of constitutionalization as a system of global governance. The fourth section explores the concept of constitutionalization from diplomacy to the rules based international system. The fifth section explicates a few basic trends of harmonization between international law and domestic legal regulatory practices. The sixth section discusses the problems and possible trends of global constitutionalism. The final section concludes with a notion that despite diversity, in all its likelihood, Asia seems to be gradually advancing its role from a bystander to the partner of global constitutionalism, in terms of transmuting concepts into international rules, harmonizing them at the domestic level, and implementing them in practice.

\section{Is International Law Eurocentric or Universal?}

Rules of international law relating to treaties, war, peace, diplomacy, protection of diplomats, consular agencies, systems of arbitration, international trade and business, piracy and asylum among others, were historically developed in ancient civilizations. The United Nations High Commission for Refugees (UNCHR) mentions that the practice of granting asylum to people fleeing persecution in foreign lands is one of the earliest hallmarks of civilization. The UNCHR further claims that references have been found in texts written 3,500 years ago in the Middle East, such as the Hittites, Babylonians, Assyrians, and Egyptians. ${ }^{1}$ Also, the concept of the freedom of high seas and common heritage of mankind was already developed in Asia and practiced in the Indian Ocean before Grotius developed the same idea in Europe. ${ }^{2}$

Nevertheless, the European literature written in the area of international law is full of assertions of a European prerogative over the origins of modern international law. For example, Oppenheim claims that international law as the law of the international community of states, “. . . dutifully traces it back to Hugo

1. See UNCHR, Refugees, available at http://www.unhcr.org/pages/49c3646c125.html visited on July 17, 2013.

2. See Garry Buzan \& Richard Little, World History and the Development of non-Western International Relations Theory, in Non-Western International Relations Theory: Perspectives on ANd Beyond Asia 213 (Amitav Acharya \& Barry Buzan eds., Routledge, 2009). 
Grotius as its father." ${ }^{3}$ He purely argues that on the publication of the Law of War and Peace, ${ }^{4}$ all subsequent legal developments between independent states were based on the idea of Grotius. Perhaps, Oppenheim accurately visualized the colonial and war-ridden undertakings of European states, which drew justifications from the Grotian idea of 'just war.' However, Oppenheim's account might turn out to be an overstatement because it is far from being reflexive to the academic traditions and political practices of non-European countries in the world. Similarly, J. G. Stark readily concludes that the early references to international law in different parts of the world including in China, Egypt, India, and Islamic traditions did not make any serious contribution to the development of international law. He claims, “. . . it would be wrong to regard these early instances as representing any serious contribution towards the evolution of the modern system of international law." ${ }^{5}$ Without any disinclination, Stark appreciates only the contribution of European states for the development of international law. ${ }^{6}$ Further, Brierly also gives credit to the 1648 Westphalian system as the foundational stone in designing the character of the modern international law, ${ }^{7}$ which was in fact immediately shattered. ${ }^{8}$

However, Bandyopadhyay intensely questions how the European prerogative over international law, impregnated with imperialistic ideas, could be acceptable to the global community as the ideal prototype of modern international law;

3. See L. Oppenheim, The Future of International Law, Ebook 23 (The Clarendon Press, 1921).

4. See Hugo Grotius, The Law of War and Peace, Kindle Location 726 (Lonang Institute, Kindle 2010 / 1625). Grotius maintains that, "It is sufficiently well established, therefore, that not all wars are at variance with the law of nature; and this may also be said to be true of the law of nations."

5. See J. G. Stark, An Introduction to International Law 7 (Butterworths, 1977).

6. Id.at 6 . He claims that, "The modern system of international law is a product roughly speaking of only the last four hundred years. It grew to some extent out of the usages and practices of modern European states."

7. See J. L. Brierly, The Law of Nations: An Introduction to the International LaW of Peace 1-5 (The Clarendon Press, rep. 1989). Brierly mentions, "Rules which may be described as rules of international law are to be found in the history both of the ancient and medieval worlds; for ever since men began to organize their common life in political communities they have felt the need of some system of rules, however rudimentary, to regulate their inter-community relations. But as a definite branch of jurisprudence the system which we now know as international law is modern, dating only from the sixteenth and seventeenth centuries, for its special character has been determined by that of the modern European state system, which was itself shaped in the ferment of the Renaissance and the Reformation."

8. For detail discussion on the issue see generally David OnNekink, WaR AND RELigion After WestPHALIA 1648-1713 (Ashgate, 2009). 
among others, as it had denied the 'right to self-determination,' the foundation of sovereignty. ${ }^{9}$ Justice Owada contends that the Eurocentric explanation of international law grown on the basis of Christian theology was the hallmark of the expansionist policies of Europe. ${ }^{10}$ In fact, Montesquieu had already refuted the European claim over the European origination of international law. In 'The Spirit of Laws,' Montesquieu clearly mentions that, "The law of nations is naturally founded on this principle that different nations ought in time of peace to do one another all the good they can, and in time or war as little injury as possible ... All countries have a law of nations, not excepting the Iroquois themselves, though they devour their prisoners; for they send and receive ambassadors, and understand the rights of war and peace ..."11

R. P. Anand maintains the thesis that “. . Asia was familiar with the language of international law from early times and that founding figures like Hugo Grotius borrowed from the doctrines and practices of Asian states." ${ }^{2}$ Fassbender and Peters succinctly expose how the history of international law has so far been written projecting Europe as the progenitor of international law, driven by the ideals of Enlightenment in the name of progress and humanity, which is seemingly beautiful but realistically false. They claim, "The Eurocentric story of international law has proven wrong because it is incomplete." 13 Ambitiously and analytically, the Eurocentric explanation of international law hides the proper understanding of international law from its historical perspectives especially by committing errors in mirroring the images of the widely practiced doctrines of international law from across the globe. Thus, Keeton and Schwarzenberger contend that 'viewed in isolation, international law is unlikely to reflect accurately the genesis of contemporary international law.' ${ }^{14}$ Glahn penetratingly shows that any examination of Assyrian, Babylonian, early Chinese,

9. See Pramathanath Bandyopadhyay, International Law and Custom in Ancient India Ebook 1-3 (Calcutta University Press, 1920).

10. See Hisashi Owada, Asia and International Law, 1 Asian Journal of International Law 6-7, 8-11 (2011).

11. See M. de Montesquieu, The Spirit of Laws 39 (The Library Fund Inc. 2010/1777).

12. Referred in B. S. Chimni, The World of TWAIL: Introduction to the Special Issue, 3 TRADE L. \& Dev. 17, 14-25 (2011).

13. See Bardo Gassbender \& Anne Peters, Introduction: Towards a Global History of International Law, in The Oxford Handbook of the History of International Law, Kindle Location 1398 (Bardo Gassbender \& Anne Peters eds., Oxford University Press, 2012).

14. See George W. Keeton \& George Schwanzenbenger, The Frontiers of International Law 43 (Stevens \& Sons, 1962). 
Hebrew or Hindu records in the fields of warfare and diplomacy reveal many customs and usages which are still part of the practices of modern states. ${ }^{15}$

Especially in the post-colonial era, scholarship from outside the Western world is regaining its historical momentum by unearthing records and knowledge bases. For example, the work, Africa: Mapping New Boundaries in International Law, powerfully unfolds the fact that the credit for the world's first constitutional government goes not to Europe but to Africa. Indeed, it also contends that the highly developed ancient African civilization of Egypt and Nubia, among others, had pioneered international rules relating to international trade, commerce, war, diplomacy, and treaty-making with the rigor of some conceptual affinity to modern international law. ${ }^{16}$ States in the ancient Indian continent had, two thousand years before Grotius, Rachel or Ayala recalled Europe to humanity, propounded a body of rules governing the sovereign states. ${ }^{17}$ In short, the Eurocentric explanation of international law can be understood anachronistic from both historical facts and scholastic traditions. ${ }^{18}$ In fact, Orakhelashvili argues that any assertions about the Eurocentric origin of international law “. . . are not only conceptually flawed, but are also unsupported by evidence. The origins of international law lie outside Europe, and at no stage of its development has international law been a truly European system." ${ }^{19}$

In short, the Euro-centric claim over the prerogative on the origination of international law is indeed exceedingly gratuitous and fluid. Certainly, the understanding about the origin and development of international law would be more apposite to recognize if articulated not in spatial terms, but in terms of universal conceptual attribution, influence, continuity, and vivacity. The historically endured concept of constitutionalization of international rules in governing international relations thus gains its exuberance from having originated beyond any cultural and regional specific boundaries. Against this

15. See Bardo Gassbender \& Anne Peters, Introduction: Towards a Global History of International Law, in The Oxford Handbook of the History of International Law, Kindle Location 1398 (Bardo Gassbender \& Anne Peters eds., Oxford University Press, 2012).

16. See generally Jeremy Levitt, Introduction - Africa: A Maker of International Law, in AFrICA: Mapping New Boundaries in International Law (Jeremy Levitt ed., Hart Publishing, 2008).

17. See Bandyopadhyay, supra note Ebook 6.

18. See Upendra Baxi, Some Remarks on Eurocentrism and the Law of Nations, in Asian StateS and the Development of Universal International Law 3 (in R. P. Anand ed., New Delhi, Vikas Publication, 1972).

19. See Alexander Orakhelashvili, The Idea of European International Law, 17 THE EuRoPEAN JOURNAL OF INTERNATIONAL LAW 315, 315-347 (2005). 
background, this paper explores the nature of the idea of constitutionalization of international relations and argues that any spatially fragmented explanation of international law is inadequate. However, at the same time it aims to examine the 'Asian Approach to International Law,' in respect to Asian contribution to the development and institutionalization of international law, specifically the concept of constitutionalism. The following part of this paper will discuss the nature of the Asian approach to international law.

\section{Is there any Uniform Asian Approach to International Law?}

Besides some exceptions to multilateralism such as regionalism and bilateralism, any other forms of spatial fragmentations of international law are unassumingly elusive in their approaches. Having said that, some Asian scholars have reassuringly chosen the term 'Asian Approaches to International Law, ${ }^{20}$ perhaps to be more reflexive of the Asian diversity. Also, other Asian scholars have contended the inappropriateness of any such description due to deep variations in the constitutive processes, structure, and facts of international law in Asia. For example, Chimni argues that, "Both essentialist/civilizational explanation and a crude materialist understanding of an Asian approach to international law need to be rejected." ${ }^{21}$ Positively, the same standard could be applied to any other spatially fragmented approach to international law. At the same time, the growing Asian stimuli in changing the current structure of Western domination in the formulation and institutionalization of concepts into the framework of international law should be supportive of explicating international law from conceptual bulwark instead of engaging in any spatial fragmentations. ${ }^{22}$ The conspicuous roles played by Asia, Africa, and Latin America from the independence movement to making international rules through negotiations such as the Doha Round exemplify the changing dynamics, particularly in counterbalancing the unilateral and dominant role of the West in constitutionalizing international relations. Unfortunately, in the real world, 'hegemony invariably

20. See generally Jin-Hyun Paik, Seok-Woo Lee, \& Kevin Y. L. Tan eds., Asian Approaches to International LaW and the Legacy of Colonialism (Routledge, 2012).

21. See B. S. Chimni, Is there an Asian Approach to International Law: Questions, Thesis, and Reflections, 14 Asian Yearbook of International LaW 249 (2008).

22. See generally Surendra Bhandari, Making Rules in the WTO: Free or Managed Trade (RoseDog Books, 2012); see also Zou Keyuan \& Jianfu Chen, Introduction: The Rise of Asia, in International LaW in EAst Asia (Zou Keyuan \& Jianfu Chen eds., International Law in East Asia, Ashgate, 2011). 
exercised in some degree by the dominant powers' poses serious challenges to global constitutionalism.

The emergence of the constitutionalism of international law, especially in the post-war era, as the achievement of humankind is not European exclusively, nor it is typically American, Latin American, African, or Asian. It is rather fashioned by the common and universal aspirations of humankind. Nevertheless, the practical realm of designing concepts and transmuting them into the construct of international rules has overwhelmingly been Westernized, which is one of the reasons for the global disenchantment and backlash to the constitutionalism of international law or global constitutionalism. At the same time, academic disagreements about the global constitutionalism have also been preoccupied with the issues of descriptive and conceptual dissonances. Some of these objections about the departure of international rules from statist legacy to the regime of an emerging world society exceedingly suggest global constitutionalism as a cipher. ${ }^{23}$ Despite objections, in recent days, works in the area of constitutionalization of international relations are growing immensely. ${ }^{24}$ However, one of the gaps discernible in the academic discourses persists on the basic demand for the conceptualization or operationalization of global constitutionalism.

\section{Chart 1: Forms and Concept of Constitutionalism under International Law}
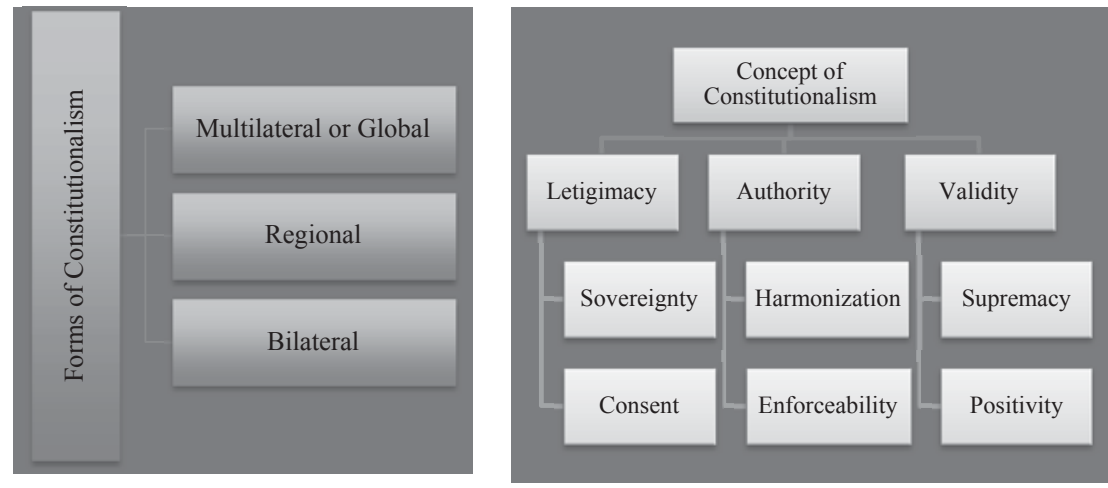

23. See Lars Viellechner, Constitutionalism as a Cipher: On the Convergence of Constitutionalist and Pluralist Approaches to the Globalization of Law, 4 GotTingen Journal of InTERNATIONAL LAW 600, 599-623 (2012).

24. See generally Jan Kalbbers, Anne Peters, \& Geir Ulfstein, The Constitutionalization of International Law (Oxford University Press, 2009); see also Jeffrey Dunoff and Joel P. Trachtman eds., Ruling the World Constitutionalism, International Law, and Global Governance (Cambridge University Press, 2009); Karolina Milewicz, Emerging Patterns of Global Constitutionalization: Toward a Conceptual Framework, 16 Indiana Journal of Global Legal Studies 413-436 (2009); Nicholas Tsagourias ed., Transnational Constitutionalism: International and European Perspectives (Cambridge, Cambridge University Press, 2007). 
To address the gap, the chart above distinguishes constitutionalism under international law in its three forms and three conceptual features. Multilateral or global constitutionalism, regional constitutionalism, and bilateral framework are the three forms. In terms of conceptual features, bilateral framework is a weak one to be presented as constitutionalism in its strictest sense. Also, except the case of European Union, conceptually fulfilling regional constitutionalism is yet to be matured. Thus, out of these three forms, this paper mostly focuses only on the multilateral or global constitutionalism. The concept of global constitutionalism consists in its three fundamental features: legitimacy, authority, and validity. These three features also warrant a regime of global governance built upon the actual system of global constitutionalism. Also for analytical convenience, each of these three features consists of two important conceptual subsets (altogether six conceptual subsets). For example, sovereignty and consent ensure legitimacy. Harmony and enforceability constitute authority. Supremacy and positivity institutionalize validity.

This paper argues that modernity or modern international law is a reflection of global constitutionalism, which is not confined to any categories of temporal and spatial exclusions or explanations. Though, both temporal and spatial features help guarding concept in more specific context. Correspondingly, the framework of global constitutionalism is thus the foundational concept of international law, which distinguishes modernity from other appellations on the basis of six integral conceptual subsets: sovereignty, consent, harmonization, enforceability, positivity, and supremacy. With consent, sovereign states enter into and manage international relations by creating international laws. When sovereign states impart their consent through the process of ratification or accession (except for self-executing treaties), they are required to harmonize their domestic laws, policies, and administrative mechanisms compatible with international law. Moreover, the requirements of compatibility purport to make sure that international laws are faithfully enforced at the domestic level. If the member states or parties violate or do not implement international law, by exercising its supremacy over the domestic law, the international law requires member states to implement international law as validated by its positive foundation. In short, these six subset concepts provide necessary framework for the constitutionalization of international law and defining the modernity of international law. In absence of any of these six subset concepts, it is hard to conceive the constitutionalization of international law and secure its modernity. However, the answer to the question of what constitutes the modernity of 
international law is often misunderstood, erroneously explained, and chauvinistically designed. For example, as discussed above, often the so-called claims about European origins and privileges over international law produce misunderstandings, erroneous explanations, and chauvinistic designs in regard to tracing Europe as the origination spot of modern international law. This spaceladen percept of modernity is not corroborated by any standard of conceptual analysis.

Sovereign equality as the basis of consent reinforces the appropriate process of the legitimacy of international rules as one of the foundational concepts of modern international law, which also existed in the ancient practices of international law in Asia. It is not strange, however, to find that much of the European literature on international law inaccurately exemplifies the Treaty of Westphalia, 1648, as the benchmark of the modern concept of sovereignty. Perhaps it is accurate in the context of Europe but it is not factual in the context of Asia and world at large. Moreover, modern commentators reject the Westphalian order, since it was primarily a non-constitutional order. ${ }^{25}$ Even in the nineteenth century, Brougham Leech had logically refuted any claims they would only produce illogical inference that no such science of international law had ever existed before the work of Grotius. ${ }^{26}$ Leech clearly projects that ancient civilizations had developed the science of law for the recognition and continuation of independent political communities and the role of consent in making international rules. ${ }^{27}$ The Asian practices of negotiations and the creation of treaties with consent in ancient civilizations were composed of the same ingredients of sovereignty and were drawn from the same awareness of legitimacy that we find in modern international law. ${ }^{28}$ However, these historical treasures capable of exemplifying the Asian approach to international law suffered attrition from being overlooked and distorted for centuries. Nevertheless, the ancient practices of negotiations and conclusion of treaties by the consent of sovereign states in Sumer, Assyria, Persia, India, China, Greece, Rome, and Islamic tradition provide ample evidence on the historical existence of the concept of legitimacy in the realm of international law. ${ }^{29}$

25. See Jan Kalbbers, Anne Peters, \& Geir Ulfstein, The Constitutionalization of International Law 8 (Oxford University Press, 2009).

26. See H. Brougham Leech, An Essay on Ancient International Law, Kindle Location 47 (Dublin, Printed at the University Press, Ponsonby and Murphy, 1877).

27. Id.

28. See generally id; see also R. P. AnAND, supra note.

29. See generally Adam Watson, The Evolution of International Society pp. 21-134 (Routledge, 
Against this background, this paper contends that the concept of constitutionalization of international law exists in Asia from ancient periods to the present day, excluding some exceptions like the traditional Chinese concept of vassal states. ${ }^{30}$

Harmonization of domestic laws, administrative mechanisms, and judicial practices, and enforcement of international law at the domestic level constitute major foundational stones of modern international law, which despite some deficiencies in institutional underpinning, also existed in the ancient Asian practices of international law. The lodestar of entering into treaties, from ancient periods to the present, is invariably the very idea of compliance. The concept of pacta sunt servanda and the sanctity of treaties applied in the regulations of inter-state conduct in ancient Asia show the existence of the notion of authority under international law. ${ }^{31}$ Furthermore, the recognition of the binding nature of a treaty by Kautilya further suggests the practical value and authority of treaties in managing inter-state relations. ${ }^{32}$ Though, to ensure the harmonization and enforceability of international law at the domestic level, international institutions and international courts existed like in the present day were certainly absent in those days. Nonetheless, the practices of arbitration and diplomatic missions in solving disputes between states were common in ancient Asian traditions. ${ }^{33}$

Transmutation of normative standards into a valid, legitimate, and enforceable regime warrants a positive order. A normative standard for achieving legitimacy through the accomplishment of a rule-making process commands authority in the form of institutionalized apparatus, further ensuring the implementation of the legitimized standards. However, the legitimate and authoritative standards may lack validity, which reminds us of the conditions of rule by law. On the contrary, the rule of law condition, where validity, legitimacy, and enforceability exist in a unified whole or harmony, constructs a positive order. The idea of positivism and the supremacy of constitutional order found both at the domestic and international levels present the unique achievements of modern

Rep. 2010); see also Bandyopadhyaya supra note; Coleman Phillipson, The International Law and Custom of Ancient Greece and Rome Vol. 1 \& 2 (MacMillan and Co. Ltd, 1911); W. A. P. Martin, Traces of International Law in China, XIV The InteRnational Review 63-77 (1883).

30. See Zang Shiming, A Historical and Jurisprudential Analysis of Suzerain-Vassal State Relationship in the Quing Dynasty, 1 Front. Hist. China 124-157 (2006).

31. See generally R. P. ANAND, supra note at 31-36.

32. Id., at 34-36.

33. Id. 
legal systems, which were also envisioned in ancient Asian legal political practices. For example, law, justice, and governance were closely interlinked in Buddha's concept of social political systems. Buddha considered law as the instrument, which grafts the system of reward and punishment with the idea of righteousness. ${ }^{34}$ Buddha's reverence to law was extraordinary. He considered that the follower of law would possess true knowledge and serenity of mind. ${ }^{35}$ Dhammapada, a collection of verses being one of the canonical books of Buddhism, claims that, "If an earnest person has roused himself, if he is not forgetful, if his deeds are pure, if he acts with consideration, if he restrains himself, and lives according to law, then his glory will increase." ${ }^{6}$ For Buddha, law was not a divine order but a positive order created through human virtue for the promotion of universal humanity. His idea of human virtue was not suitable only to a domestic order, but also applicable to the international order as well.

The idea of virtue commonly found in the philosophical traditions of Buddha, Confucius, Socrates, and Plato among others explain the validity of an international system. Like Buddha, Confucius also saw both virtue and ethics as standards, which could transform the individual and social life into peace, harmony, and justice both at the local and inter-state levels. Confucius saw social order in the form of a justified duty that would lead to the welfare of an individual, state, and international community. Confucius maintained that, "He who entertains thoughts contrary to justice will act contrary to reason." ${ }^{7}$ Justice was the standard of governance for Confucius. ${ }^{38}$ The Confucian system of justice embodies two important ideas: reason and the 'right thing to do.'39 The Chinese word zhengyi is the counterpart of the English word 'justice'. Zheng means setting things right and rectifying things, and $y i$ means righteousness, truth, fitness, or the right principle. Thus, the term zhengyi connotes setting things right and

34. See Charles Eliot, Hinduism and Buddhism: an Historical Sketch Ch. X, EBook 582 (London, Routledge \& Kegan Paul Ltd., Vol. 1, Reprint 1962/1921).

35. See F. Max Muller trans., The Dhammapada Ch. 1, verse 20 (EBook, The Project Gutenberg, 2008). Verse 34 provides that, "If a man's thoughts are unsteady, if he does not know the true law, if his peace of mind is troubled, his knowledge will never be perfect."

36. See id., verse 24 .

37. See Robert K. Douglas, Confucianism and Taouism, Ebook 371 (London, Society for Promoting Christian Knowledge, 1879).

38. See id., at 171 .

39. In recent days, the concept of a 'right thing to do' has been made popular by Michael Sandel by interpreting justice as a concept of right thing to do. See generally Michael J. SANDEL, Liberalism AND the Limits of Justice (Cambridge University Press, $2^{\text {nd }}$ ed., 1998). 
allowing righteousness to stand straight. ${ }^{40}$ The Buddhist and Confucian ideas about law suggest the importance of legitimacy, authority and validity applicable both at the domestic and international levels.

In short, in the absence of legitimacy, authority, and validity, international law loses its foundation of existence, operation, and universality. The Asian approach to international law, in an inclusive style, symbolizes the idea of constitutionalism both in its ancient contributions, and the post-war contributions to international law. The early Asian thoughts and practices, especially from the ancient Indian sub-continent and China, have played an important role in diffusing the concept of constitutionalizing international relations. In the post-war era, like other continents, Asia is also underwriting the concept of constitutionalization manifested further in global, and plural discourses (regional and bilateral) of international law. As the global constitutionalism outlines the modern character of international law, the European initiatives before the establishment of the United Nations merely provided conflicting and parochial conceptual references to the idea of constitutionalism, especially because of three factors. First, under the system of colonization, the system of constitutionalism under international law could not exist both conceptually and practically. Further, colonialism ruthlessly shattered the universal cause of humanity. Second, as a product of a gun-powered civilization, the system of just war legitimized in the pre-UN European age had disgracefully divided the whole world into civilized, high-civilizations, and primitive arrangements. For European colonizers, Europe (broadly the West) was the only civilized world. For them, China, India, and Japan were not civilized but were high-civilized countries, and the rest of the world was primitive and thus not civilized. ${ }^{41}$ This incoherent and offensive European understanding of civilization and international law was the actual foe of the concept of constitutionalism under international law. Third, the idea of constitutionalization of international relations has specifically been entrenched by the UN Charter. Thus, modern international law and its features of constitutionalism conclusively begin only with the institutionalization of the UN Charter, which is not a sole product of Europe or any other particular regime.

Nevertheless, due to the power and interest led mechanism of the veto system under the UN Security Council; time and again the powerful countries have chipped away at the constitutionalism of international law, which has been

40. See Xunwu Chen, Justice: The Neglected Argument and the Pregnant Vision, 19 Asian PhiLosophy 191, 189-198 (2009).

41. See Immanuel Wallerstein, World-Systems Analysis, pp. 8-10 (Duke University Press, 2004). 
discussed in the following passages. In this context, a more unpretentious system of constitutionalism under international law can be found in the World Trade Organization (WTO), and the Statute of the International Criminal Court (ICC), among others. Nevertheless, the WTO system of the constitutionalism also suffers from a number of conceptual biases. ${ }^{42}$ Though, more succinctly, it reflects the features of constitutionalism compared to many other regimes of international law. Against this background, the Asian Approach to international law is analyzed in reference to constitutionalism under the UN including the human rights conventions, ICC, and the WTO systems.

Although academic underpinnings in the area of the 'Asian Approach to International Law' is significantly growing in recent times, including the 'Third World Approach to International Law' (TWAIL), the distinctive features of the 'approach,' in particular an 'Asian approach' to international law, demands more specific and clear methodological structure and understanding. As suggested in the chart below, this paper appreciates the 'Asian approach' in seven different features as a frame of reference to analyze the system as an integrated structure.

\section{Chart 2: Basic Features of the Asian Approach}

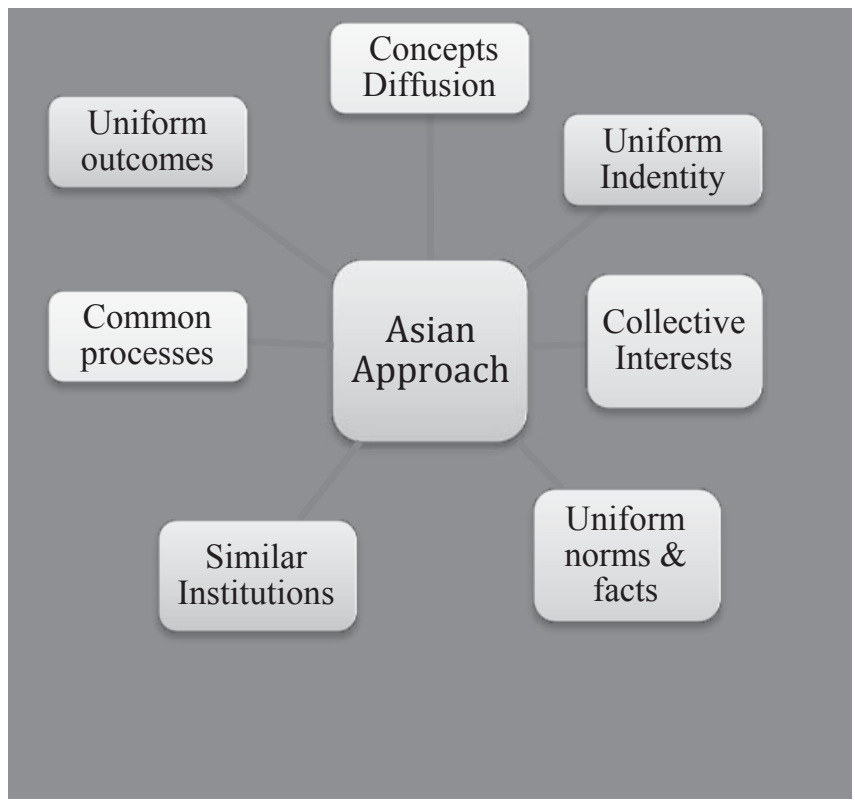

42. See BHANDARI, supra note. 
At the conceptual level, the case of an Asian Approach to international law refers to a number of ideas. The seven ideas listed in Chart II, are in no case exhaustive. It is also because Asia as a region with vast cultural, civilizational, and philosophical diversities might not be confined to any specific structures. However, the concept of constitutionalism as the building block of international law allows appreciating the 'Asian approach' in these seven different methodological frameworks for analytical convenience and conceptual clarity.

The seven features of the 'Asian approach' to international law consist in the diffusion of concepts, a uniform identity, collective interests, uniform norms and facts, the existence of similar institutions, common processes, and uniformity in outcomes. As the home of multiple religions, civilizations, cultures, and political ideologies, in common, Asia often lacks these features on social, political, economic, cultural, and legal domains, which are also reflexive to the issue of international law. Against this background, as claimed by Chimni, it would be comfortable to reject the idea of the 'Asian approach' to international law. But at the conceptual level, especially on the count of diffusion of concepts, Asia is historically hospitable to universal, and pluralist concepts of international law, which is especially germane to the concept of constitutionalizing international relations.

In the post-Cold War era, as we are experiencing the growing role of international law in shaping the process and outcomes of the globalized world with the idea of constitutionalism, the role of Asia cannot be viewed outside of the framework of the constitutionalization process. Thus, in the following sections, this paper analyzes the Asian approach to international law within the framework of constitutionalism. Understandably, today's world governs international relations not only by the standards of diplomacy, but also largely by the standards of international rules, which institutionalize the foundation of global governance. With the heightened role of international law in the legitimization and regulation of international relations through the vantage point of the global constitutionalism, the Asian approach coexists mainly as the part of the following four processes:

- Constitutionalization of International Institutional Order or Global Governance,

- Constitutionalization of International Relations: From Diplomacy to Law,

- International Relations: Harmonization of Domestic Rules and Practices, and

- Global Constitutionalism.

Each of these processes is discussed below under separate headings. 


\section{Constitutionalization of International Institutional Order or Global Governance}

A spectacular rise of international institutional order comprehended in the post-war era appears confident in espousing the system of global governance. Certainly, Asia is a part of global governance. Global governance is progressively getting deeper with the constitutionalization of international relations. Pascale Lamy vividly outlines the basic features of global governance. He links governance systems on national, regional and international levels as three states of mass: solid, liquid, and gaseous. He argues a governance deficit arises when citizens are left behind in participating in all these forms of governance. He offers four fundamental principles of global governance: the rule of law, subsidiarity, coherence, and integration. He clearly puts forward the idea that global governance must be anchored in the system of the rule of law that enforces international commitments. Governance decisions should be taken on the basis of the principle of subsidiarity, i.e. taking decisions at the level at which it would be most effective to do so. The principle of coherence demands States to act in unison to give effect to their commitments. The principle of integration demands States to integrate international rules at the domestic level allowing citizens to become the part of this process and be a beneficiary of the outcome. ${ }^{43}$

Our Global Neighborhood Report, 1995, succinctly highlights the role of global governance in terms of interconnectedness driven by rules-based international relations. In the age of globalization, it also foresees the greater role for the power of people in shaping their future collectively. The establishment and institutionalization of the United Nations system draws on the universal hope for a new era in international relations. However, the onset of the Cold War had greatly diminished the fulfillment of this universal hope. With the end of the Cold War, the prospect for pursuing common objectives through multilateralism has turned out to be a high possibility. The world community seems to be uniting around the idea of collective responsibility in a wide range of areas, including not only with security in a military sense, but also in economic and social terms for sustainable development, the promotion of democracy, equity, human rights, and humanitarian solidarity. In this changed context, there is no alternative to working together using the concept of the rule of law as the instrument of

43. See WTO, Receiving Honorary Doctorate in Turkey, Lamy Warns against Remote Global Governance, (March 15, 2013), available at http://www.wto.org/english/news_e/sppl_e/sppl272_e.htm. 
collective power to create a better world, the Report claims. ${ }^{44}$ Nevertheless, Professor Kimijima argues that the problem of ensuring the rule of law as the governing standard for the UN Security Council members, especially for the five permanent members, poses a grave challenge in the realization of the rules based international relations and global governance. ${ }^{45}$ The NATO intervention in Bosnia, the US intervention in Iraq, the US presence in Afghanistan, and the politics in the Security Council in regard to stopping the grave violations of human rights in Syria corroborate the suspicions of Professor Kimijima.

\subsection{Constitutionalization of Globalization}

The development of constitutionalism under international law has brought globalization within its legalistic premise. 'Globalization' ${ }^{46}$ is not a new idea. Though, 'global constitutionalism' ${ }^{47}$ has been understood and explained from diverse perspectives. Nevertheless, the scope, and implications of global constitutionalism have become more penetrating with the growing prominence of the concept of global governance and globalization. Accordingly, globalization has become one of the most hotly debated issues, almost everywhere in the world. In recent years perhaps the debate has procured more proponents, as well as opponents, than any other international issue. Also, there has been no dearth of literature on globalization both from the proponents and opponents viewpoints. Similarly, in one way or another, every discipline is engaged in explaining and conceptualizing globalization. This paper neither intends to survey the literature on globalization, nor engages in reviewing the interdisciplinary conceptualization of globalization. Broadly, it subscribes to the idea of interconnectedness, which seems suffusing into all disciplines in conceptualizing globalization and the progression of Asia towards reaping the benefits by addressing the plausible

44. See Our Global Neighborhood: Report of the Commission on Global Governance, Chapter 1 (Oxford University Press, 1995).

45. See Akihiko Kimijima, Japan's Contribution to Global Constitutionalism 4 Societies Without BoRders 105-116 (2009).

46. See Priest Tyler, The History of Globalization (Kendall Hunt Publishing, 2012); see also Jurgen Osterhammel \& Niels P. Petersson, Globalization: A Short History (in Dona Gyer trans., Princeton University Press, 2009); Alexander Mc Gillivary, A Brief History of Globalization: the Untold Story of Our Incredible Shrinking Planet (Robinson Publishing, 2006).

47. See generally Christine E. J. Schwobel, Global Constitutionalism in International Legal Perspective (Martinus Nijhoff, 2011); see also Kimijima, supra note; Andreas L. Paulus, The International Legal System as a Constitution, in Ruling the World? Constitutionalism, International Law, and Global Governance 69 (Jeffrey L. Dunoff \& Joel P. Trachtman eds., Cambridge University Press, 2009). 
challenges. In this new environment, as projected by the Asian Development Bank, with its most successful trend of economic growth and human development, Asia might regain its historical strength with 51 percent of global GDP by $2050 .{ }^{48}$

The institutionalization of global constitutionalism as a positive framework could be comprehensively appraised with the appreciation of the normative aspects of globalization as well. As shown below in the chart III, this paper divides globalization into two categories: positive and normative. On the positive level, international rules facilitate and govern international relations with the institutionalized nature of global governance founded on uniform standards, harmonization of domestic rules, and the supremacy of international rules in the framework of global constitutionalism. The global constitutionalism entrenched in legitimacy, authority, and validity in all stages of law creation, implementation, and adjudication can be termed as legalism. Against this background, the following chart will help to estimate the concept of globalization.

\section{Chart 3: Constitutionalization of Globalization}

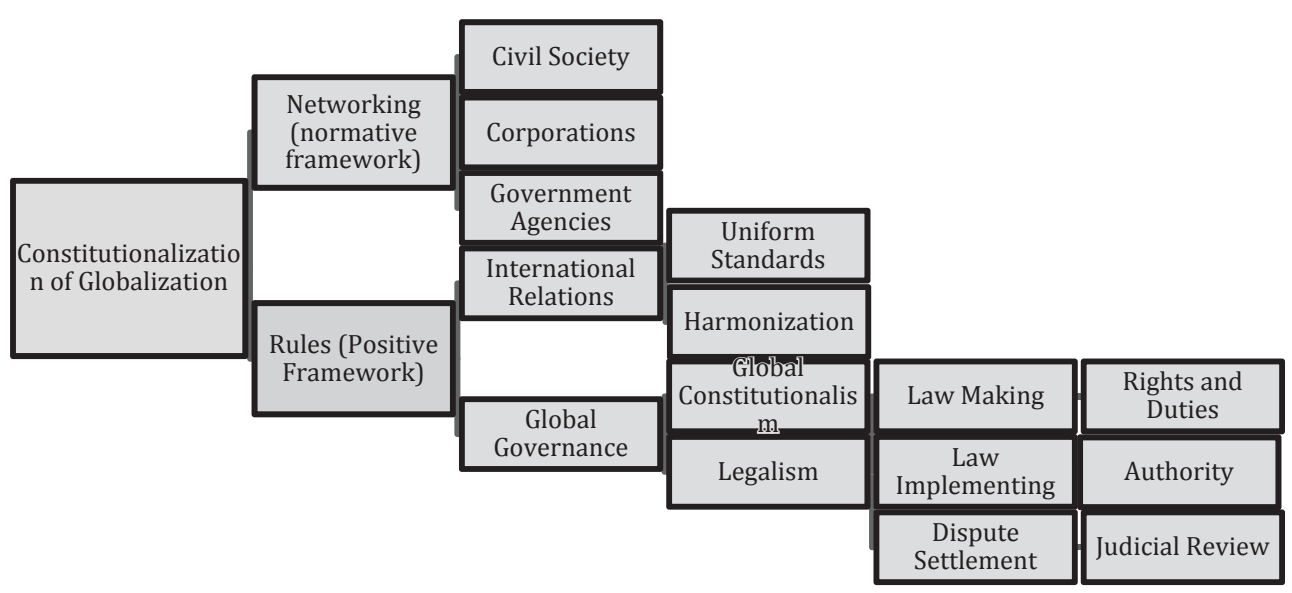

The distinction of the normative side of globalization could be better understood in terms of processes, outcomes, and implications of interconnectedness of individuals, communities, companies, institutions, and governments, among others. For example, Alaina Podmorow, a nine year old, $4^{\text {th }}$ grade Canadian student, after attending a lecture by a journalist decided to help and raise funds for the education of the poor, discriminated, and neglected women in Afghanistan. Alaina started an

48. See ADB, Asia in 2050: Realizing the Asian Century, 2011. 
organization called Little Women for Little Women in Afghanistan. ${ }^{49}$ A 68-year old former local government employee of Japan, Mr. Yujiro Ishimaru is constructing school buildings in remote areas of Nepal to provide educational opportunities to poor children. He has already constructed 40 schools and is planning to construct 60 more schools, in memory of his daughter. Already, more than 13,000 students have benefited from Ishimaru's philanthropy. ${ }^{50}$ Perhaps, these normative initiatives at the individual level stand out as the succinct examples of interconnectedness for a global cause. These normative initiatives could never be realized unless there would exist a supportive system governed by international and domestic rules.

As a part of civil society engagement, INGOs and NGOs are serving from one corner of the world to the other for the development and well-being of communities. When poverty, disease, or natural disasters hit communities hard; the global community promptly shows its solidarity offering unselfish support. Whether it is the Fukushima disaster or devastations from earthquakes in Chile or Solomon Islands, no matter where they are, the international community is not silent. Instead, it acts with a deep sense of morality and responsibility at the normative level. Communities are not only interested in knowing what is happening only in their own communities, but they are equally keen to know what is happening elsewhere around the globe. Outstandingly, they stand up for the cause of global justice and welfare. Flagrant violations of human rights in one part of the world are not concerns only for that part of the world, but they instantly become issues of global concern. Whether it is the case of the gang rape of a young girl on a bus in India, ${ }^{51}$ or other cases of human rights violations in Libya, Syria, Afghanistan, China, or Nepal, the global community is disposed to denounce and resist injustice not only suffered by them, but also suffered by human beings across the globe. Straightforwardly and instantaneously, public

49. For detail information, please visit: http://www.littlewomenforlittlewomen.com .

50. See Japan Times, Benefactor Builds Schools in Nepal, (Jan. 17, 2012), available at http:// www.japantimes.co.jp/news/2012/01/17/national/benefactor-builds-schools-in-nepal/\#. USxErqUyHdk .

51. A 23-year-old medical student was victim of an hours-long gang rape on a bus in New Delhi on Dec. 16, 2012. Six men raped the girl, damaged her organs and body with iron rods on a bus while driving around the city before stripping and dumping her on the side of the road. The girl passed away, while undergoing treatment in Singapore. This instant of cruelty sparked public outrage not only in India, but also across the globe. For detail information visit on http://www. indianexpress.com/fullcoverage/delhi-gangrape/467; http://www.breakingnews.com/topic/newdelhi-gang-rape-case ; http://www.ndtv.com/article/india/south-africa-girl-dies-after-rapecomparison-made-to-indian-case-327511; http://indiatoday.intoday.in/section/240/1/delhi-gangrape. html. 
opinions cross the artificial boundaries of communities and countries. Amazingly, communities are interconnected more responsively than ever before. However, both international and domestic laws play catalytic role in transmuting the normative activities by legitimizing them into positive rules. In fact, the positive rules may either foster or retard the normative activities of interconnectedness.

When there were few routes of trade, such as the Silk Road, Chinese silk would take more than eighteen months to reach Rome. ${ }^{52}$ Except the Emperor and a few rich people, hardly any consumers could even think of buying silk. Today, goods produced in any part of the world can easily, quickly, and inexpensively travel across borders. Consumers worldwide have abundant choices of what to buy and consume. In many cases, companies launch their products in different parts of the world at the same time so that the consumers can have access to their products straightaway. The age of consumption requirements on local or national products has almost become a bygone case. Largely, the process of trade liberalization ushered by the WTO, which seems to further deepen in the future, has unleashed today's markets globally. Markets, producers, and consumers all are interconnected globally, as if they are inseparable. However, the interconnectedness could hardly be flourished in the absence of facilitating environment created by international law. This premise leads to conceive law as the designer of globalization or it can be termed as the constitutionalization of globalization.

\subsection{International Law as the Designer of Globalization}

Not only individuals and businesses, but also institutions and governments

52. See William J. Bernstein, A Splendid Exchange: How Trade Shaped the World, Kindle Location 138-148, (Perseus Books Group, Kindle Edition, 2009). "How did goods get from China to Rome? Very slowly and very perilously, one laborious stage at a time. Chinese traders from southern ports loaded their ships with silk for the long coastwise journey down Indochina and around the Malay Peninsula and Bay of Bengal to the ports of Sri Lanka. There, they would be met by Indian merchants who would then transport the fabric to the Tamil ports on the southwest coast of the subcontinent-Muziris, Nelcynda, and Comara. Here, large numbers of Greek and Arab intermediaries handled the onward leg to the island of Dioscordia (modern Socotra), a bubbling masala of Arab, Greek, Indian, Persian, and Ethiopian entrepreneurs. From Dioscordia, the cargo floated on Greek vessels through the entrance of the Red Sea at the Bab el Mandeb (Arabic for "Gate of Sorrows") to the sea's main port of Berenice in Egypt; then across the desert by camel to the Nile; and next by ship downstream to Alexandria, where Greek Roman and Italian Roman ships moved it across the Mediterranean to the huge Roman termini of Puteoli (modern Pozzuoli) and Ostia. As a general rule, the Chinese seldom ventured west of Sri Lanka, the Indians north of the Red Sea mouth, and the Italians south of Alexandria. It was left to the Greeks, who ranged freely from India to Italy, to carry the greatest share of the traffic." 
are interconnected. International institutions decide what rate of customs duty governments should levy on goods and services imported and exported. The levels of protection to be offered to the owner of intellectual property rights are also decided at the international level. At the international level, governments also settle what environmental standards the producers should maintain in producing goods and services. Not only trade and environmental issues are decided at the international level, but also the issues of human rights, security, peace, and development are discussed, negotiated, and decided. No government can claim that human rights abuses fall exclusively into its domestic affairs immune from any international introspection and monitoring. No government can claim the sovereign right over harboring terrorists and violators of international criminal law. No government can insist on its sovereign integrity or domestic laws as an excuse for defaulting on the decisions of international judicial organs such as the International Court of Justice (ICJ), Dispute Settlement Body of the World Trade Organization (WTO), and International Criminal Court (ICC), among others. This said, for Asian legal traditions, the Medellin case decided by the US Supreme Court in 2008, which found the decision of the ICJ not binding unless Congress enacts an implementing law appears as an uncomfortable legal concept. This is because Asia has barely defied the authority of the ICJ or the WTO ever since their establishment. In particular, the development of global constitutionalism, besides some exceptions in regards to Iraq, Myanmar, and North Korea, Asia adopted a way for coexistence in a global society by promoting the idea of global governance that vanguards the supremacy of international laws over domestic laws and policies.

The idea of interconnectedness can be understood with different levels and forms. Moral, social, economic, cultural, and political or other arrangements are some of the expressions of the forms of interconnectedness. Along with these several arrangements, interconnectedness could also be split into at least two further levels: binding (i.e. legalistic or positive) and non-binding (e g. networking or normative) arrangements or regimes. From the above discussion it can be deduced that the global interconnectedness has been culminated into the rulesbased system of global constitutionalism and governance. From a regime perspective, globalization could be better called a binding regime. The very idea of a binding regime expressed through the concept of constitutionalism and governance constitutes the subject matter of law, international relations, and globalization. In this respect, law functions either as a tool or a master of globalization. As a master, law designs the process, defines the nature, and shapes 
the progression and direction of globalization. Indeed, globalization has elegantly cultivated the idea of law as a ruler.

A few decades ago, Woodrow Wilson observed that, "You will see that international law is revolutionized by putting morals into it." ${ }^{33}$ This is especially more true in the field of international relations than in any other field, since international relations are not simply governed by moral standards reflected in domestic theories, policies, and diplomacy, but are overwhelmingly managed by rules-based international standards. In this regard, it is obvious that concepts of internationalization of standards and globalization of standards conspicuously influence the nature of international relations. Peter Singer vividly distinguishes the concepts of internationalization and globalization. He attributes internationalization to the old mode of international relations under which the conception of a nation-state or the traditional idea of sovereignty is not only recognized, but also given a determining status. Beyond the traditional idea of sovereignty, Singer deliberates globalization as a form of standard, which requires the conceptual transformation of sovereignty into a new form, with the recognition of the supremacy of international rules for the governance of international relations. ${ }^{54}$

Our Global Neighborhood Report powerfully observes that, "The rule of law has been a critical civilizing influence in every free society. It distinguishes a democratic from a tyrannical society; it secures liberty and justice against repression; it elevates equality above dominion; it empowers the weak against the unjust claims of the strong. Its restraints, no less than the moral precepts it asserts, are essential to the well-being of a society, both collectively and to individuals within it. Respect for the rule of law is thus a basic neighborhood value. And one that is certainly needed in the emerging global neighborhood." ${ }^{55}$

As a medium of the formal expression of interdependence and cooperation among nations, international law has uniquely been assuming the role of a designer of the process of international relations and globalization, especially with the growing recognition of the supremacy of international rules over domestic rules. The changing socio-economic and political relations at the global level,

53. Cited in Sir Arthur Watts KCMG QC, The Importance of International Law in The Role of Law in International Politics: Essays in International Relations and international Law 12 (Michael Byers ed., Oxford University Press, reprinted 2009).

54. See generally Peter Singer, One World: The Ethics of Globalization (Yale University Press, 2002, Kindle edition).

55. See supra note Our Global Neighborhood, Chapter 6. 
inspired by the idea of a rules-based international system, have instilled the nature of international relations beyond the preoccupied limits of diplomacy. At the same time, the dynamics of globalization have also penetratingly necessitated the adjustments of legal concepts along with the pace of socio-economic and political transformations. ${ }^{56}$ In this process, law itself has been globalized. Similarly, laws of Asian countries have been globalized in the sense of harmonizing international rules at the domestic level, and instilling the supremacy of international rules over domestic laws and practices. In this new environment, the Asian legal culture has been deepen further in strengthening constitutionalization of international relations as a bedrock for the most efficient way of coexistence, security, and progress, which can also be termed as the reflection of global welfare.

\section{Constitutionalization of International Relations: From Diplomacy to Law}

Whether it is Kautliya's economics ${ }^{57}$ or Greek philosophical writings, ${ }^{58}$ there is common evidence of the role of diplomacy in managing socio-cultural, political, and economic relations among states, especially between neighboring states in the early days of political history. In today's world, it is not only neighboring states that matter. Non-state actors from remote parts of the world also matter for both good and bad. For example, Alaina Podmorow, a nine-year-old Canadian girl (16 years old in 2013) could initiate solidarity for the education of deprived women in Afghanistan. At the same time, a terrorist group, Al Qaida, working from the remote hills of Afghanistan could create unprecedented cruelty and a devastating massacre of innocent people with their actions in September 2001. The point is that international relations are more connected than ever before. States cannot operate by remaining in isolation. They cannot avoid engaging with each other for better relations, cooperation, coexistence, and solidarity for addressing common problems and enlarging opportunities both at normative and positive levels. The name of this engagement, in other words this paper terms, as a movement from

56. See Surendra Bhandari, Court-Constitution \& Global Public Policy: A Study on the Nepalese Perspective, pp.208-216 (Democracy Development and Law, Kathmandu, 1999).

57. See Kautilya's Arthasasthra (R. Shamasastry trans., Spastic Cat Press, 2009).

58. Euphernus, quoting Thucydides stated that in the case of a king or imperial city nothing was unjust, which was expedient. Referred in Hugo Grotius, The Law of War and Peace [De Jure Belli AC PACIS] Kindle Location 90 (Francis W. Kelsey trans., Lonang Institute, 2010). 
Global Constitutionalism and the Constitutionalization of International Relations: A Reflection of Asian Approaches to International Law

diplomacy to law.

Willingly or unwillingly, a state is bound to look outside its borders in order to understand and protect itself. It cannot remain disinterested and disengaged in things that happen around the world. What is more, to some extent every state is conditioned to the activities of not only other states but also non-state actors across the globe. Once Jean-Jacques Rousseau expressed that when a group of states forms a closely knit system, the involvement of many self-willed political actors imposes upon each state a continuous awareness that the others have interests and purposes distinct from its own, and that the things other states do or may do limit and partly determine its own policies. ${ }^{59}$

Diplomacy expressed in the form and essence of managing good relationships, promoting cooperation and opportunities, building solidarity by addressing common problems, and protecting local and global interests through dialogues, negotiations, and engagements among countries has always remained at the core of international relations but often resulted in the benefit of the powerful. Bederman informs us that around $2100 \mathrm{BC}$ a solemn treaty was concluded between Lahash and Umma in Mesopotamia, largely corresponding to modernday Iraq, northeastern Syria, southeastern Turkey, and southeastern Iran, defining boundaries of the neighboring countries. The treaty was inscribed in stone. Nussbaum apprises that around 1100 BC, Egypt and Hitties had concluded a treaty for peace, brotherhood, and a defensive alliance. ${ }^{60}$ Since then, countless bilateral, regional, and multilateral treaties have been concluded across the world to regulate international relations. Whether it is the 1648 Treaty of Westphalia; ${ }^{61}$ the 1919 Treaty of Versailles; ${ }^{62}$ the Charter of the United Nations, $1945 ;{ }^{63}$ or the WTO Agreement, $1994 ;{ }^{64}$ or other numerous multilateral, regional and bilateral

59. Cited in Adam Watson, Diplomacy Kindle Locations 293-296 (Taylor \& Francis, Reprint ed., 2007).

60. Referred in Malcolm N. Shaw, International Law 14 (Cambridge University Press, 6th ed., 2008).

61. See Peace Treaty between the Holy Roman Emperor and the King of France and their respective Allies, done at Munster in Westphalia, the 24th Day of October 1648.

62. See The Versailles Treaty of June 28, 1919, available at http://avalon.law.yale.edu/imt/ parti.asp .

63. See Charter of the United Nations and Statute of the International Court of Justice, signed on 26 June 1945 in San Francisco, at the conclusion of the United Nations Conference on International Organization, and came into force on 24 October 1945, available at http://www. un.org/en/documents/charter/index.shtml.

64. See the WTO Agreement, 1994 which includes General Agreement on Tariffs and Trade, 1994 (GATT); General Agreement on Trade in Services, 1994 (GATS); General Agreement on 
treaties; there seems to be a conspicuous trend of diplomatic initiatives of consultations, dialogues, and negotiations often resulting into a positive framework of law. In this context, Steve Smith observes that this positive framework of law or positivism has been largely accountable for both the character and content of international theory in recent days. ${ }^{65}$

Traditionally, the concept that 'war begins when diplomacy fails' had dominated the regime of international relations. With this concept, diplomacy was centrally integrated into the prescient and periphery of war: to develop alliances, secure territory and people, expand territory through war, enter into peaceful arrangements, and so on. Among these traditional features, expanding territory through war has now been declared illegal ${ }^{66}$ and has been contained to a larger extent in the present day. No matter, whether it was in the era of Kautliya's realism, ${ }^{67}$ Sun Tzu's Art of War,${ }^{68}$ Chinggis (Genghis) Khan's mastery of war, ${ }^{69}$ the Treaty of Westphalia, $1648 ;^{70}$ or the First and Second World Wars; all have ended

Trade Related Aspects of Intellectual Property Rights, 1994 (TRIPS); Understanding on Rules and Procedures Governing the Settlement of Disputes, 1994 (DSB); Trade Policy Review Mechanism, 1994 (TPRM); and Plurilateral Trade Agreements, 1994 (PTAs); available at http:// www.wto.org/english/docs_e/legal_e/legal_e.htm .

65. See Steve Smith, Positivism and Beyond, in International Theory: Positivism and Beyond 11 (Steve Smith, Ken Booth, \& Marysia Lalewski eds., Cambridge University Press, 1996).

66. See Article 2.4 of the UN Charter, which provides that, "All Members shall refrain in their international relations from the threat or use of force against the territorial integrity or political independence of any state, or in any other manner inconsistent with the Purpose of the United Nations."

67. Kautilya's discussion of war and diplomacy are fascinating and far-reaching. He wished his King to become a world conqueror. He understood states as natural allies and inevitable enemies. He perceived treaties as instruments of serving interests and power and to be broken if they do not serve the interests. Truly, Kautilya was truly ancient founder of realism. For detail discussion, see Roger Boesche, Kautilya's Arthasastra on War and Diplomacy in Ancient India, 67 Journal of Military History 9-37 (2003).

68. See generally Sun Tsu, The ART of WAR (Ralph D. Sawyer trans., Basic Books, 1994). The main idea of the book can be summarized as: He who relies solely on warlike measures shall be exterminated; he who relies solely on peaceful measures shall perish. If you know the enemy and know yourself, you need not fear the result of a hundred battles. If you know yourself but not the enemy, for every victory gained you will also suffer a defeat.

69. See Jeremy Black, A History of Diplomacy, Kindle Location 96 (Reaktion Books, 2010). In the thirteenth century, Chinggis Khan had sent an envoy to the Governor of Otran, even after the Governor had massacred a caravan of Mongols. Chinggis Khan still wanted to trade and settle the dispute without war. But when his envoy was also executed, his control of repose and tranquility was removed and could be quenched only by the shedding of blood.

70. See supra note 62. The Treaty of Westphalia is considered one of the legitimate sources of transforming international relations into the domain of positivism. It championed the idea of rules-based governance of international relations based on the idea of sovereignty. Shaw claims 
up with a transformation of international relations into a positivist direction, i.e. rules-based governance of international relations. In today's world, the instruments of international treaties manage most international relations issues. Nevertheless, the role for diplomacy in the creation of international rules, and maintaining confidence of coexistence between governments is unwaveringly important. Obviously, diplomacy pursued beyond the boundary of law (domestic and international) loses its legitimacy and validity. Diplomatic activities cannot ignore or violate law. In this sense, modern diplomacy is disciplined within the purview of the rule of law, which succinctly conveys the connection between law and diplomacy.

However, some international political science scholars, especially from the West, have contested the connection between law and diplomacy. They have maintained that international law and international organizations that administer international laws are essentially irrelevant to a proper understanding of international politics and consequently progressive development of international political theory. ${ }^{71}$ Stanley Hoffman in 1971 concluded that the irrelevance of international law and organizations would persist until the world returned to the conditions of relatively simple placidity that supposedly characterized its formative period. ${ }^{72}$ Boyle adds, in other words, international law and international organizations would not become relevant to international politics in the foreseeable or even distant future. ${ }^{73}$ Further, Boyle argues that the application of legal methods to address the international political problems is thoroughly inadequate and also counterproductive. ${ }^{74}$ Leading authorities such as E. H. Carr \& Hans J. Morgenthau had also rejected the significance of international law in the realm of international relations. These realists had argued that, when it comes to the crunch, international law does not have impact

that positivism developed as the modern nation-state system emerged, after the Peace of Westphalia in 1648, from the religious wars in Europe. See Malcolm N. Shaw, International LaW 26 (Cambridge University Press, 6th ed., 2008). See also, S. Beaulac, The Westphalian Legal Orthodoxy-Myth or Reality? 2 Journal of History of International LaW 148-177 (2000); C. Harding \& C. L. Lim eds., Renegotiating Westphalia (Martinus Nijhoff, 1999); L. Gross, The Peace of Westphalia1648-1948, 42 American Journal of International Law 20-41 (1948).

71. See Francis Anthony Boyle, World Politics and International Law 3 (Duke University Press, 1995).

72. Referred in id., at 4.

73. Id. at 4 .

74. Id., at 5-6. 
on state behaviors. ${ }^{75}$ Besides some exceptions, such as the recurrent reluctance to govern international relations based on the principle of constitutionalization among some South Asian countries, traditional sense of rivalries between regional powers, and some democratic deficiencies; on the whole, Asia in the post-war era, especially in the post-Cold War era, seems to have been constructively engaged in promoting international relations on the foundation of international rules and global constitutionalism. ${ }^{76}$

Armstrong, Farrell, and Lambart claim that the argument that international law has had no impact on contemporary world politics and that states can do as they please is hard to credit. ${ }^{77}$ Basac Cali considers observations that ignore the role of international law in international relations as cynical expressions. He suggests that the cynics regard international law as an enterprise of the naïve, the occupation of wishful thinkers, or the realm of the fools who do not understand international politics. Cali argues that the cynical view is incorrect. ${ }^{78}$

What the events and evidence demonstrate is that the perspective disintegrating the connection between international law and international relations is either exaggerated or speculative. For example, there are numerous areas of international relations, some of them can be stated as: war, weapons, use of force, peace, security, human rights, trade, business, investment, intellectual property rights, environment, conservation of natural resources, sustainable development, use of the sea, air and space, international crime, and the exchange and protection of diplomats. All these major areas of international relations are now governed by international laws. But the question arises of whether international law is effective in governing the behaviors of powerful states or not. With some examples of the use of force, let us examine the issues of connection between international relations and international law in conjunction with the perspective of the effectiveness of international law.

75. Referred in David Armstrong, Theo Farrell, \& Helene Lambert, International Law and International Relations, Kindle Location 110 (Cambridge University Press, 2nd ed., 2012).

76. For detail discussion see Robert A. Dayley, \& Clark D. Neher, Southeast Asia in the New International Era (Westview Press, 2013); see also Amitav Acharya, The Making of Southeast Asia; International Relations of a Region (Cornell University Press, 2013); Michael J. Green, \& Bates Gill, Asia's New Multilateralism: Cooperation, Competition, and the Search for Community (Columbia University Press, 2008); David Shambaugh, \& Michael Yahuda, International Relations of Asia: Asia in World Politics (Rowman \& Littlefield Publishers, 2008)

77. Id., Kindle Location 123.

78. See Basac Cali, International Law or International Relations 2 (Oxford University Press, 2010). 
Until the adoption of the UN Charter in $1945,{ }^{79}$ the use of force was not prohibited in a legal sense. Article 2.4 of the UN Charter clearly prohibits the use of force in conducting international relations. Article 51 allows the use of force in the form of self-defense until the Security Council takes appropriate measures under Chapter VII of the UN Charter. Any state using force for self-defense should immediately inform the Security Council and receive permission from the Security Council for further action. Until the Security Council takes any decision, the force used in self-defense should not exceed the limit of necessity and proportionality. ${ }^{80}$

A number of treaties had imposed a system of self-restraint, ${ }^{81}$ but had not prohibited the use of force in the conduct of international relations before the establishment of the UN. The system of the League of Nations, ${ }^{82}$ influenced by the Westphalia Treaty, 1648, had failed to outlaw war and the use of force. In one or

79. For example Article 2.4 of the UN Charter prohibits the use of force. It provides that, "All Members shall refrain in their international relations from the threat or use of force against the territorial integrity or political independence of any state, or in any other manner inconsistent with the Purpose of the United Nations." Article 51 allows using force only for self-defense, until the Security Council takes necessary measures.

80. See Nicaragua v. United States (Military and Paramilitary Activities in and against Nicaragua), I.C.J. Reports 1984, p. 392. In this case the ICJ has established that the prohibition on the use of force constitutes a jus cogens norm of international law, specified in Article 2.4 of the UN Charter. However, right to self-defense is one of the exceptions to the rule of jus cogens. Nevertheless, the exception should only be used within the purview of limitations established in the Caroline incident: the use of force in self-defense should not exceed the limit of necessity and proportionality.

81. For example, The Covenant of the League of Nations (Covenant), 1919; and The Kellogg-Briand Pact or the Paris Pact of 1929 had provided the system of self-restrain. Preamble of the Covenant had provided that, "In order to promote international cooperation and to achieve international peace and security, by the acceptance of obligations not to resort to war, $\cdots$ Agree to this Covenant of the League of Nations." Similarly, Article 10 of the Covenant had provided that, "The Members of the League undertake to respect and preserve as against external aggression the territorial integrity and existing political independence of all Members of the League. In case of any such aggression or in case of any threat or danger of such aggression the Council shall advise upon the means by which this obligation shall be fulfilled."

82. For example, Article II of the Westphalia Treaty, 1648, had devised the system of self-restrain, which reads, " $\cdots$ the Hostilities have been practiced, in such a manner, that no body, under any pretext whatsoever, shall practice any Acts of Hostility, entertain any Enmity, or cause any Trouble to each other; neither as to Persons, Effects and Security, neither of themselves or by others, neither privately nor openly, neither directly nor indirectly, neither under the color of Right, nor by the way of Deed, either within or without the extent of the Empire, notwithstanding all Covenants made before to the contrary: That they shall not act, or permit to be acted, any wrong or injury to any whatsoever; but that all that has passed on the one side, and the other, as well before as during the War, in Words, Writings, and Outrageous Actions, in Violence, Hostility, Damages and Expenses, without any respect to Persons or Things, shall be entirely abolished in such a manner that all that might be demanded of, or pretended to, by each other on that behalf, shall be buried in eternal Oblivion." 
another form, until the establishment of the United Nations, the actors and institutions were preoccupied with the idea of "just war," despite numerous efforts to regulate war. ${ }^{83}$ Since history, there were always efforts to regulate war through the means of law, but the attempts had often failed. ${ }^{84}$ Rulers often manipulated politics to deny or reduce the authority of law. A ruler, Marius, declared that the din of arms made it impossible for him to hear the voice of law. ${ }^{85}$ The egotism of unruly political tendencies in regulating international relations had always stood as a serious problem, until it was brought under the regime of law for the first time with the establishment of the United Nations. Though, this unruly egoistic tendency often provoked by ideology and politics has made a number of attempts to undermine the authority of law, even after the establishment of the United Nations.

Early in 1946, the Security Council (SC) faced the issue of the continuation of the USSR army in Iran beyond the Tri-partite Agreement concluded on January $29,1942 .{ }^{86}$ Immediately another issue was raised in the SC of whether the presence and activities of the Franco regime in Spain would endanger international peace. The SC established a five-member Sub-Committee to investigate the matter. ${ }^{87}$ On the investigation of the matter, the $\mathrm{SC}$ took a decision that, ". . . to keep the situation in Spain under continuous observation and maintain it upon the list of matters of which it is seized, in order that it will be at all times ready to take such measures as may become necessary to maintain international peace and security." ${ }^{8}$ The $\mathrm{SC}$ also received the issue of alleged border violations along the frontier between Greece on the one hand and Albania, Bulgaria, and Yugoslavia on the other. ${ }^{89}$ The case of the Corfu Channel was more sensitive since Albania was not a Member of the UN. Nevertheless, with the efforts of the SC, Albania agreed to negotiate the issue and submit the case before

83. See Hugo Grotius, The Law of War and Peace [De Jure Belli ac Pacis] Kindle Location 90 (Francis W. Kelsey trans., Lonang Institute, 2010).

84. Roman writer Ennius believed that there was nothing more common than the assertion of antagonism between law and arms. Horace also described that for Achilles laws declared by him were not ordained for him but for others because by dint of arms he claimed for himself. Referred in Hugo Grotius, The Law of War and Peace [De Jure Belli ac Pacis] Kindle Location 90-98 (Francis W. Kelsey trans., Lonang Institute, 2010).

85. Id.

86. See the Security Council Resolution S/RES/3, April 4, 1946.

87. Id. S/RES/4, April 29, 1946.

88. Id. S/RES/7, June 26, 1946.

89. Id. S/RES/12, Dec. 19, 1946. 
the ICJ agreeing to bear all obligations as arising to being a Member of the UN. ${ }^{90}$ The UN moved to a new venture with the establishment of the UNTSO to monitor the Armistice Agreement between Israel and its Arab neighbors. ${ }^{91}$ The SC also established the United Nations Military Observer Group in India and Pakistan on the issue of Kashmir dispute, which started working in January $1949 .{ }^{92}$ Since then, both of these peacekeeping operations (PKOs) are ongoing.

The above facts show that the UN had worked comparatively smoothly in the beginning. With the ideological division of the world into two camps, the USSR and US entered into the Cold War. The long gestation period of the Cold War was drawn-out until 1990, which presented a number of challenges to the effective application of the positivist instrumentality of international law in regulating international relations. The Korean War broke out on June 25, 1950, posing a litmus test to the competence of the UN in maintaining peace. The General Assembly (GA) had already recognized the independence of the People's Republic of Korea on November 14, 1947, and had also established a Commission to accomplish an election for a representative government. ${ }^{93}$ Against this background, the SC took decisions that the aggression on South Korea by North Korea was a breach of peace and first time invoked Article 51 of the UN Charter for collective defense of South Korea under the Unified Command led by the US. ${ }^{94}$ Since the Korean War, the application of the collective defense system under Article 51 of the UN Charter became possible only in 1990, with the SC Resolution 660 of August 2, 1990, demanding Iraq's unconditional withdrawal of its military force from Kuwait.

With the ensuing deadlocks in the SC, the UN resorted to the Uniting for Peace Decision ${ }^{95}$ to assume the role of Security Council in maintaining peace and

90. Id. S/RES/20, Jan 20, 1947; S/RES/22, April 9, 1947.

91. Id. S/RES/50, May 29, 1948.

92. Id. S/RES/39, Jan 20, 1948; S/RES/41, April 21, 1948.

93. See the General Assembly Resolution A/RES/112(II) A, Nov. 14, 1947.

94. See the Security Council Resolutions S/RES/82, June 25, 1950; S/RES/83, June 27, 1950; S/ RES/84, July 7, 1950; S/RES/85, July 31, 1950. These decisions were taken on the backdrop of the boycott of the Security Council by the Soviet Union in protest of the Council's failure to replace the Republic of China's seat with the recently established People's Republic of China. For detail discussion, see William Stueck, The United Nations, The Security Council, and the Korean War, in The United Nations Security Council and War: The Evolution of Thought and Practice SINCE 1945, Chapter 11 (Vaughan Lowe, Adam Roberts, Jennifer Welsh, \& Dominik Zaum eds., Oxford University Press, 2010).

95. See UN General Assembly Resolution 377 A (V), Nov. 3, 1950. Section 1 of the Uniting for Peace Decision reads as, "Resolves that if the Security Council, because of lack of unanimity of 
security. However, the decision largely set-off peacekeeping missions to address the problems of conflicts, which did not remain unchallenged. Some powerful countries stopped paying their membership fees to the UN, claiming that the expenses of the UN, relating to PKO in Congo (ONUC) ${ }^{96}$ and the Middle East (UNEF) ${ }^{97}$ followed by the Suez Canal controversy, were not legitimate. The General Assembly requested the ICJ for its advisory opinion. In its advisory opinion, the ICJ upheld the legality of the UN Peacekeeping Missions even though the UN Charter does not specifically mention these measures. ${ }^{98}$ Since then, the UN has deployed 67 PKOs; with 54 of them being deployed after $1988 .{ }^{99}$

How far these PKOs have been successful deserves to be an important question for examination. Nevertheless, the UN peacekeeping, originally developed as a means of dealing with inter-State conflict, has increasingly been applied to intra-State conflicts and civil wars. ${ }^{100}$ UN PKOs have increasingly been undertaking a wide variety of complex tasks, from helping to build sustainable institutions of governance to human rights monitoring, from security sector reform to the disarmament, demobilization and reintegration of former combatants, and from institutionalizing democracies to strengthening the rule of

the permanent members, fails to exercise its primary responsibility for the maintenance of international peace and security in any case where there appears to be a threat to the peace, breach of the peace, or act of aggression, the General Assembly shall consider the matter immediately with a view to making appropriate recommendations to Members for collective measures, including in the case of a breach of peace or act of aggression the use of armed force when necessary, to maintain or restore international peace and security. .."

96. See the UN General Assembly Resolution.

97. See the UN General Assembly Resolution First Emergency Special Session, 997(ES-I), October 30, 1956. The First United Nations Peacekeeping Force was named United Nations Emergency Force (UNEF I) established by the first emergency special session of the General Assembly held from 1-10 November 1956. The mandate of the UNEF I was to secure and supervise the cessation of hostilities, including the withdrawal of the armed forces of France, Israel, and the United Kingdom from the Egyptian territory, after the withdrawal, to serve as a buffer between the Egyptian and Israeli forces and to provide impartial supervision of the ceasefire. The UNEF I was withdrawn in May-June 1967 at Egypt's request.

98. See Elina Steinerte \& Rebecca Wallace, International Law: Nutcases 196 (Sweet \& Maxwell, 2008).

99. See UN, History of Peacekeeping, available at http://www.un.org/en/peacekeeping/ operations/history.shtml .

100. See Dilek Latif, United Nation's Changing Role in the Post-Cold War Era, XXX The Turkish Yearbook 28, 23-66, (2000). Latif argues that peacekeeping operations had been invented for conflict management. It was a concept not found in the Charter, but came into usage from the special needs of the Cold War situation. Otherwise, the UN would have been completely irrelevant to the maintenance of international peace and security because of the superpowers competition and continuous veto. 
Global Constitutionalism and the Constitutionalization of International Relations: A Reflection of Asian Approaches to International Law

law. ${ }^{101}$ On the whole, these PKO activities give evidence for the rules-based approach of international relations.

However, during the Cold War and even in the post-Cold War period, there have been many instances, which show the disrespect and violation of international rules. For example, the decade of 1980 s saw a troublesome period in UN history. In 1979, American diplomats were taken hostage in Iran when the revolutionary government came into power. The Iranian government ignored the decisions of the SC. Fighting between China and Vietnam did not end. The French, and US involvements in the Vietnam War had challenged the rules-based system of international relations. In the meantime, the USSR invaded Afghanistan in December 1979. The Iran-Iraq war also began in September 1980. The SC could not invoke collective defense measures and remained a passive spectator. What is more, the decade also witnessed conflicts in Northern Ireland, guerrilla warfare in Malaysia, civil wars in Chad, Nicaragua, Salvador, Sri-Lanka, and Sudan. Most notably, the American-Vietnam War and the US military involvement across the globe $^{102}$ defied the UN Charter and the rules of international law. Among others, the Israeli attack on Lebanon in $1968,{ }^{103}$ the Israeli attack on Tunisia in $1985,{ }^{104}$

101. See UN PKO, Peacekeeping Operation: Principles and Guidelines, 2008, available at http://pbpu.unlb.org/pbps/library/capstone_doctrine_eNg.pdf .

102. See Wayne Bert, American Military Intervention in Unconventional War: From the Philippines to Iraq (Palgrave McMillan, 2011); see also Brad D. Lookingbill, American Military History: A Documentary Reader (Wiley-Blackwell, 2010); Richard N. Hass, Intervention: The Use of American Military Force in the Post-Cold War World (Carnegie Endowment for International Peace, 1999); Ivan Musicart, The Banana War: A History of US Military Intervention in Latin America (McMillan Pub. Co., 1990). For detail list of American military actions visit http://www.thirdworldtraveler.com/Blum/US_Interventions_WBlumZ.html.

103. The Israeli air force attacked Beirut airport in Dec. 1968. Israel attempted to justify this action as a response to the earlier terrorist attack on an Israeli plane at Athens airport. Israel claimed that Lebanese government had permitted Arab terrorist organizations to set up their headquarters in Beirut and to maintain a training base in Lebanon. The attack on an Israeli plane at Athens airport had violated the ceasefire between Israel and Lebanon, and Israel was entitled to rights of self-defense. However, the SC had unanimously denounced the Israeli attack with its Resolution 262 of 1968 . The US also joined the condemnation. The US said that Lebanon had not in fact been responsible for the terrorist attack on Athens airport and the Israeli action was not proportionate. However, the US maintained that the Israeli action was based on the inherent right of self-defense. Other States in the SC did not agree with the interpretation of the US.

104. Israel attacked Tunisia in 1985 in response to terrorist attacks on Israelis abroad by the PLO. Israel claimed that Tunisia had a duty to prevent such attacks but did not fulfill it. The SC condemned Israeli attack by 14-0-1 votes and found the Israeli conception of self-defense was very far from that of international law. The US supported the Israeli claim. 
US action against Libya in 1986, ${ }^{105}$ the US invasion of Panama in $1989,{ }^{106}$ the US action in Iraq in $1993,{ }^{107}$ the US action against Al-Qaida in $1998,{ }^{108}$ NATO action in Kosovo in $1999,{ }^{109}$ US action in Afghanistan in $2001,{ }^{110}$ and the US action in Iraq in $2003,{ }^{111}$ are some of the pertinent issues in regard to the violation of the

105. The US attacked Tripoli in 1986 in response to Libya's involvement in terrorist attack against US citizens abroad. The US reported the action to the SC as self-defense under Article 51 of the UN Charter. The US claimed that it had taken action against Libya in response to past terrorist attacks on its nationals and also to deter Libya in the future. Most of the Members in the SC rejected the US claim saying that self-defense should be narrowly interpreted and could not be used pre-emptively. However, the SC could not take the decision to condemn the US actions since the UK and France supported the US. The UK claimed that the right to selfdefense was not a passive right.

106. See Lawrence A. Yates, The US Military Intervention in Panama: Origins, Planning, and Crisis Management, June 1987-December 1989 (Amazon Digital Service, Kindle Edition, 2012).

107. The US blamed Iraqi intelligence for the alleged assassination attempt on ex-President George Bush I in Kuwait in April 1993. The US responded in June 1993 by firing missiles at the Iraqi Intelligence Headquarters in Baghdad. The US reported the action to the SC as an act of self-defense under Article 51 of the UN Charter. The SC showed considerable sympathy with the US, with only China condemning the US. Some commentators argue that this lead to a turning point in the arena of international law on terror, allowing a flexible approach to the invocation of right to self-defense.

108. The US responded to the terrorist attack by Al Qaida on its embassies in Kenya and Tanzania in August 1998 by missile attacks on a terrorist training camp in Afghanistan and a pharmaceutical plant in Sudan. The US reported its action to the SC under Article 51 of the UN Charter. The US claimed that the actions were attempts to bring Afghanistan and Sudan to comply with international law. Sudan requested a meeting in the SC, but it did not take place. Arab States, NAMA, Pakistan, and Russia condemned the US.

109. The SC had found that the deteriorating situation in Kosovo was threating international peace. It had also noted that the situation was leading towards a humanitarian catastrophe. On 13th October 1998, NATO had issued activation orders for air strikes against the Federal Republic of Yugoslavia (FRY) to commence four days later, unless the FRY complied with the requirements of SCR. 1199. Slobodan Milosevic agreed to withdraw troops with NATO, UN welcomed the agreement. But the situation did not improve. NATO began air strikes on 24th March 1999 until 10 June 1999. India and Russia proposed the SC to take a resolution condemning the NATO invasion. UNMIK was established by the SC Res. 1244 .

110. In the post-9/11 situation, the US started "Operation Enduring Freedom (OEF)" in Afghanistan on 7th October 2001 with the military assistance from the UK, France, Germany, Australia, Canada, and others. President Bush announced that the US would make no difference between a terrorist and those who harbor them. The US informed the SC under Article 51 stating that Al-Qaida was operating from Afghanistan with the support of Taliban regime. The US claimed that the action was based on self-defense, yet the SC did not specifically give permission like in the Iraq War 1990, SC Resolution 678. Though, no states in the SC condemned the US action.

111. UN Secretary-General Kofi Annan said that, 'from our point of view and the UN Charter point of view, it was illegal.' The US Permanent Representative to the UN, Ambassador John Danforth responded that, 'We don't agree with the Secretary-General . . Consider there were 16 
collective defense measure under Article 51 of the UN Charter.

After 9/11 the question is: has there been a significant change in international law, especially in regard to the extension of Article 51, to non-state actors with or without complicity of a state? Particularly, with the SCR 1373 of 2001 two schools of thought have emerged. The first, still with the obsession of realism, argues that even in the absence of permission from the SC, actions can be taken against terrorists and actions for humanitarian interventions can be carried out in critical humanitarian situations as a responsibility to protect. ${ }^{112}$ The second school considers that the legal requirements under Article 51 of the UN Charter are not conditional to the events of terrorism or humanitarian situations; preconditions of the UN Charter should be fulfilled in resorting to the use of force even in the case of a self-defense. ${ }^{113}$ The ICJ in the Israel-Palestine Wall case took opportunity to interpret Article 51 of the UN Charter and the SC Resolutions 1368 \& 1373 in its Advisory opinion. The ICJ observed that Article 51 of the UN Charter allows selfdefense only in the case of an armed attack by one state against another state and further held that these Resolutions did not support the Israeli claim of constructing a wall in the name of a self-defense. ${ }^{114}$ The demand for the application of the so-called doctrine of right to protect beyond the scope of Article 51 has now clearly lost its legitimacy, though the West often advocates to exercise it beyond Article 51, whereas Asia seems constantly reluctant to any distortions of

Security Council resolutions and Resolution 1441 held that the then government of Iraq was not in compliance with the previous resolutions, which is clearly the case, and promised that there would be serious consequences if they were not in compliance. Then the question . . . for those countries that were part of the coalition was ... do all these UN resolutions mean nothing, does the Security Council mean nothing, is it totally ineffectual ... It would undercut the rule of law had there been no action ... So I think that action we took ... was required if we're going to maintain a rule of law.' Cited in Legality of US-Led Invasion of Iraq, 99 American Journal of INTERNATIONAL LAW 269-270 (2005).

112. See Nicholas Kerton-Johnson, Justifying the Use of Force a Post-9/11 World: Striving for Hierarchy in International Society, 84 International Affairs 991-1007 (2008); see also Christopher Greenwood, Humanitarian Intervention: The Case of Kosovo, Finnish Yearbook of International Law 141-175 (2002); Christopher Greenwood, International Law and War Against Terrorism, 78 International AfFaIRs 301-317 (2002); Christopher Greenwood, International Law and the NATO Intervention in Kosovo, 49 International and Comparative Law Quarterly 926-934 (2000).

113. See Ian Brownlie, International Law and the Use of Force by States Revisited, 1 CHINESE JOURNAL of International LaW 1-19 (2002); see also Ian Brownlie \& C. J. Apperley, Kosovo Crisis Inquiry: Memorandum on the International Law Aspects, 49 InTERNATIONAL AND COMPARATIVE LAW QuaRTERLY 878905 (2000);

114. See Legal Consequence of the Construction of a Wall in the Occupied Palestinian Territory, 2004 ICJ Reports 134. 
the rules based system for satiating the ambition of the realists.

The Libyan case of 2011 and the case of Mali of 2012/13 clearly establish that both humanitarian interventions and fighting against terrorism should be carried out with legitimate processes following the requirements of the UN Charter, especially the process of self-defense under Article 51 of the UN Charter. In the face of colossal violations of human rights in Libya, the SC made a 'No Fly Zone' decision, which clearly authorized the Member States acting nationally or through regional organizations or arrangements, to take all necessary measures to enforce compliance with the decision. ${ }^{115}$ To defeat terrorist activities, the SC authorized ${ }^{116}$ the use of force in coordination with Transitional Authority in Mali. From 11 January 2013, the French force in support of other Member countries of the UN carried out military operation called 'Operation Serval,' against terrorists in the north of Mali at the request of the Transitional Authority in Mali.

The above-mentioned cases do not cover the full spectrum of international relations; however, they do show representative trends. They mainly show some important facts and developments. First, due to the ideological division and political interests of the countries, powerful counties have especially tried to undermine the rules of international law. Nevertheless, even in the events of the violations of the rule on the use of force, the violating countries have consistently tried to defend their actions not on the whims of politics and diplomacy but on the specific grounds of law, signifying the substantial position of international law in governing international relations. Second, the international rules and institutions are products of the consent and willingness of States to regulate international relations on predetermined standards. These standards on some occasions might be unhelpful to serve the vested interests of a particular country, but on the whole they serve the interests and welfare of the global community or society. In absence of international rules and institutions, the global community becomes the victim of global anarchy. Besides some instances of the violation of international law, international law has successfully contained the scourge of global anarchy. Third, the use of force is only one of the vantage points of international relations; many other areas such as human rights, international trade, international crime, the environment, and sustainable development have been quite successfully managed under the framework of international rules. Consequently, for many states, the management of trade has turned out to be a bigger concern than the management

115. See the Security Council Resolution S/RES/1973, March 17, 2011.

116. Id. S/RES/2085, Dec. 20, 2012; S/RES/2083, Dec. 17, 2012. 
of armed conflict. ${ }^{117}$ Fourth, a few cases of violations do not mean that international law is ineffective. Both international law and domestic laws are violated on a daily basis across the globe. Most of these violations are settled either through courts or outside court proceedings. In all such cases, the bottomline of a solution is found in the posited rules. For example, actors have faithfully implemented almost all decisions of the ICJ, WTO, ICC, or other international dispute settlement bodies. In many cases, international rules are applied through the domestic process. Fifth, local interests are illusive. They are changed frequently. What is good for today might not be good for tomorrow. Mankind's common interests and universal welfare are more stable and are a real spectrum for designing stable and predictable policies or rules. Thus, the undertaking of international relations in creating global welfare cannot be achieved without a rules-based system or the rule of law in place. Thus, transformation of local political attentions into the framework of global welfare through positive standards is the propelling factor of global constitutionalization to ensure global peace and security. Sixth, with the analysis of the above-mentioned facts and events, it is easily noticeable that diplomacy and international relations are destined for a positivist system of international rules.

\section{International Relations: Harmonization of Domestic Rules and Practices}

Essentially, international relations have been globalized. The process is deepening. That is to say, they are not only internationalized, but also governed by uniform standards applicable to all countries and actors demanding harmonization of their domestic laws, policies, and administrative mechanisms to be compatible with the standards of international rules, with a few exceptions for least-developed (LDCs) and developing countries, especially in the area of international trade and environmental protections. With the advent of the idea of the most-favored nation treatment, which advanced sometime before the Second World War, the concept of harmonization advancing alongside the UN and more rigorously under the WTO. The processes of harmonization have indeed genuinely worked as cornerstones for the constitutionalization of international relations. With these developments, the process of harmonization has entrenched two conspicuous trends in international relations. First, uniform international

117. Referred in David Armstrong, Theo Farrell, \& Helene Lambert, International Law and International Relations, Kindle Location 110 (Cambridge University Press, 2nd ed., 2012). 
standards are applicable to all countries, actors, and institutions in regards to managing international relations. Second, countries are required to take necessary legislative and administrative steps in order to make their domestic laws and policies compatible with international rules. In turn, these two trends strengthen global constitutionalism.

Stephen D. Krasner summarizes the shift in international relations from 'high politics' to 'low politics.' During 1950s and 1960s international affairs were concerned primarily with military and strategic conflict, what is frequently referred to as high politics. In this period, international law was virtually neglected. A number of changes, such as independence movements, a growing focus on trade and business, concerns for sustainable development, the protection of environment, and the protection of human rights, have shifted the global focus to low politics, which turns out to be more salient for both policy makers and scholars in the post-1990 era. ${ }^{118}$

Broadly, regimes as principles, norms, rules, and decision-making procedures have standardized and converged actors' behaviors for desired outcomes. ${ }^{119}$ In other words, actors follow standard processes when engaging in international relations. Specifically, international rules standardize processes and transform norms and principles into the framework of posited rules to regulate the behaviors of actors for desired outcomes. Against this background, international relations can be perceived as the unrelenting evolvement towards global governance. ${ }^{120}$

With the shifting focus from high to low politics, more cooperative international order befitted the need of the day to be institutionalized through rules-based and uniform standards. In this connection, the UN was designed to take the lead on many issues of international relations including peace, security, human rights, environment, and sustainable development among others. The Bretton Woods system ${ }^{121}$ takes lead on the issues of financial stability,

118. See generally Stephen D. Krasner, Preface to International Regimes (Stephen D. Krasner ed., Cornell University Press, 1983).

119. See generally Stephen D. Krasner, Structural Causes and Regime Consequences: Regimes as Intervening Variables in International Regimes (Stephen D. Krasner ed., Cornell University Press, 1983).

120. For detail discussion on international relations and global governance, see Peter Kien-hong YU, International Governance and International Regimes, in IntERnATIONAL Governance, Regimes, and GloBalization (Lexington Books, 2010).

121. The Bretton Wood system consists of three institutions established in the post-war period: the World Bank (WB) for reconstructing and supporting development; the International Monetary Fund (IMF) for stabilizing monetary system and exchange rate; and the General Agreement on Tariffs and Trade (GATT), which has been succeeded by the World Trade Organization (WTO) in 
international trade, and investment among others. In the post-Cold War era, another important development has taken place in culminating the efforts of controlling international crime into the institutionalization framework of the International Criminal Court (ICC). These developments have established a new regime of international relations driven by rules-based system where uniform standards are applied and actors are demanded to harmonize their domestic laws and policies to be compatible with international rules when managing international relations. A few examples from the arena of human rights, humanitarian law, and control of international crime will elucidate the nature of this regime of harmonization.

International human rights law, regional human rights laws, and international humanitarian laws create rights for individuals and require governments to implement human rights through domestic mechanisms. For example, in the case of Hamdan v. Rumsfeld, ${ }^{122}$ the US Supreme Court found that the Common Article 3 of the 1949 Geneva Conventions was applicable to the conflict between the United States and a non-state terrorist organization, $A l$ Qaeda. Further, the Court found that if the President wished to try Al Qaeda suspects before a U.S. Military Commission, U.S. law required that the commission operate in accordance with the Common Article 3, which in turn requires that such suspects only be tried before "a regularly constituted court." The Court observed that "a regularly constituted court" is one, which should be created by statute. Thus, the Military Commission created solely by the Presidential Order could not try $A l$ Qaeda suspects. In response, the US Congress enacted the Military Commission Act (MCA) in September 2006 that allows the trial and adjudication of accused Al Qaeda members held in Guantanamo Bay.

Rights created by human rights instruments are uniform. These rights are same to all persons living anywhere in the world, ${ }^{123}$ except for a few exceptions in the case of rights specifically designed only for citizens ${ }^{124}$ or a specific group or

1995. For details on the origin of the Bretton Wood system see Benn Steil, The Battle of Bretton Woods (Princeton University Press, 2013).

122. See 126 S. Ct. 2749 (2006).

123. For example Article 7 of the International Covenant on Civil and Political Rights, 1966 provides that, "No one shall be subjected to torture or to cruel, inhuman or degrading treatment or punishment. In particular, no one shall be subjected without his free consent to medical or scientific experimentation" Article 3 further guarantees these rights both for men and women equally. Article 3 provides that, "The State Parties to the present Covenant undertake to ensure the equal right of men and women to the enjoyment of all civil and political rights set forth in the present Covenant."

124. For example Article 25 of the International Covenant on Civil and Political Rights, 1966 
sections of society. ${ }^{125}$ These rights can be enjoyed irrespective of the distinction of race, sex, color, nationality, ethnic background, or other differences. ${ }^{126}$ Any person can enjoy these rights by virtue of being an individual. States (Parties) are required to create a sufficient legal regulatory environment so that individuals can enjoy and enforce these rights. ${ }^{127}$ All parties are required to implement human rights either through giving direct effect to the international human rights laws or by harmonizing their domestic laws and policies compatible with international human rights laws. ${ }^{128}$ Many Asian countries are now parties to international human rights laws. Nevertheless, like in other parts of the world, Asia has failed to develop an Asian Convention on Human Rights and consequently an Asian Court of Human Rights.

In many cases these international human rights instruments instill the

provides that, "Every citizen shall have the right and the opportunity, without any of the distinctions mentioned in Article 2 and without reasonable restrictions: (a) To take part in the conduct of public affairs, directly or through freely chosen representatives; (b) To vote and to be elected at genuine periodic elections which shall by universal and equal suffrage and shall be held by secret ballot, guaranteeing the free expression of the will of the electors; (c) To have access, on general terms of equality, to public service in his country."

125. For example Article 27 of the International Covenant on Civil and Political Rights, 1966 provides that, "In those States in which ethnic, religious or linguistic minorities exist, persons belonging to such minorities shall not be denied the right, in community with the other members of their group, to enjoy their own culture, to profess and practice their own religion, or to use their own language."

126. For example Article 2.1 of the International Covenant on Civil and Political Rights, 1966 provides that, "Each State Party to the present Covenant undertakes to respect and to ensure to all individuals within its territory and subject to its jurisdiction the rights recognized in the present Covenant, without distinction of any kind, such as race, color, sex, language, religion, political or other opinion, national or social origin, property, birth, or other status." Similar provisions can be found in other human rights instruments as well, unless they are targeted to a specific group, such as women, or child.

127. For example Article 2.3 of the International Covenant on Civil and Political Rights, 1966 requires each State Party to undertake, "(a) To ensure that any person whose rights or freedoms as herein recognized are violated shall have an effective remedy, notwithstanding that the violation has been committed by persons acting in an official capacity; (b) To ensure that any person claiming such a remedy shall have his right thereto determined by competent judicial, administrative or legislative authorities, or by any other competent authority provided for by the legal system of the State, and to develop the possibilities of judicial remedy; (c) To ensure that the competent authorities shall enforce such remedies when granted."

128. For example Article 2.2 of the International Covenant on Civil and Political Rights, 1966 provides that, "Where not already provided for by existing legislative or other measures, each State Party to the present Covenant undertakes to take the necessary steps, in accordance with its constitutional processes and with the provisions of the present Covenant, to adopt such legislative or other measures as may be necessary to give effect to the rights recognized in the present Covenant." 
principle of erga omnes. ${ }^{129}$ In other words, some human rights issues also create obligations not only to one state but also to the international community as a whole. For example, the Convention Against Torture (CAT) creates universal jurisdiction against the acts of torture committed in any part of the world (in the territory of State Parties) requiring a State to prosecute the offender if the offender is present in the territory under its jurisdiction. ${ }^{130}$ Regional human rights courts, such as the European Court of Human Rights (ECHR), and the InterAmerican Court of Human Rights (IACHR), exercise binding jurisdiction over Member States laws and policies. ${ }^{131}$ Since 1998, the ECHR has been providing individuals direct access to the court after the exhaustion of local remedies requirements. The ECHR has rendered more than ten thousand judgments. Some of its decisions have led to significant changes in national laws. ${ }^{132}$

The 'democracy norm' under the American Convention on Human Rights, 1969, provides an interesting example of how states behaviors are shaped by international rules. In July 2009, the General Assembly of the Organization of American States (OAS) suspended Honduras after its elected government was deposed by a military coup. Similarly, there was often a tense relationship between Hugo Chavez's government of Venezuela and the US. Nevertheless, the US did not support the coup against Hugo Chavez in 2002, due to the 'democracy norm' in place. ${ }^{133}$

The uniformity of human rights standards have been given effect either through recognizing international instruments as the part of domestic legal

129. The principle of erga omnes has been lucidly established by the ICJ in Barcelona Traction Case (Belgium v. Spain), 1970 ICJ Reports 3. The ICJ held that some rights, by their very nature and importance, are rights that all states should protect and thus all states can be held to have legal obligations.

130. Article 5.2 of the Convention Against Torture provides that, "Each State Party shall likewise take such measures as may be necessary to establish its jurisdiction over such offences in cases where the alleged offered is present in any territory under its jurisdiction and it does not extradite him pursuant to article 8 to any of the States mentioned in paragraph 1 of this article."

131. For detail discussion on the issue see Elizabeth F. Defeis, The Treaty of Lisbon and Accession of the European Union to the European Convention on Human Rights, 18 ILSA Journal of International \& Comparative LaW 387-394 (2012); see also Pavelas Ravluševičius, The Enforcement of the Primacy of the European Union Law: Legal Doctrine and Practice, 18 JURISPRUDENCE 1369-1388 (2011).

132. See Jack Donnelly, International Human Rights Chapter 6 (Westview Press, 4th ed., 2013).

133. See Jack Donnelly, International Human Rights Chapter 6 (Westview Press, 4th ed., 2013). 
system or by translating them into domestic human rights laws. This process has admirably helped the process of harmonization of domestic laws and policies compatible with international rules. Despite these achievements, there still seems to be huge gaps in the realm of harmonization and implementation of international human rights instruments at the domestic level. The Freedom House survey of human rights situations at the global level designates 48 countries where the situation of human rights is not satisfactory. In fact, nine of these countries: North Korea, Turkmenistan, Uzbekistan, Sudan, Equatorial Guinea, Eritrea, Saudi Arabia, Syria, and Somalia, have been designated as countries where the situation of human rights is the worst. Another eight countries: Belarus, Burma, Chad, China, Cuba, Laos, Libya, and South Ossetia, have been designated as countries where human rights records are only slightly above those of the worst ranked countries. ${ }^{134}$ Despite the engagement in constitutionalization of international law, the field of human rights shows Asia as the part of the weakest link in the chain.

Amnesty International succinctly depicts that demands for human rights all over the world are continuing to resound. Millions have come out onto the streets of their towns and cities in a mass outpouring hopes for freedom and justice. Even the most brutal repression seemed unable to silence the increasingly urgent demands for an end to tyranny, as people showed they were no longer willing to endure systems of governance that were not built on accountability, transparency, justice and the promotion of equality. Resistance to injustice and repression took many forms, often inspiring acts of enormous courage and determination from the communities and individuals facing seemingly insuperable obstacles. In the face of indifference, threats and attacks, human rights defenders pursued legal challenges at the national and international levels against long-standing impunity and endemic discrimination. ${ }^{135}$

Despite these and many other challenges, civil society movements have enhanced public awareness and demands for the realization of human rights in Asia, which have somehow strengthened the process of uniformity and harmonization of international human rights standards. In turn, the human rights movement across the globe has also changed the landscape of international

134. See Freedom House, Freedom in the World 2012, available at http://www.freedomhouse. org/sites/default/files/inline_images/FIW\%202012\%20Booklet--Final.pdf .

135. See Amnesty International, The State of the World's Human Rights, 2012, available at http://www.amnestyusa.org/sites/default/files/air12-report-english.pdf . 
relations. As noted in the UN Charter, ${ }^{136}$ human rights have genuinely become one of the significant standards of international relations, which Asia cannot afford to ignore.

Customarily, international law treated individuals as the subject of international law, especially on two issues: piracy, ${ }^{137}$ and slave trading. ${ }^{138}$ Piracy and slave trading had long been regarded as crimes against international society. ${ }^{139}$ In modern times, the individual responsibility under international law has been expanded to many other areas including human rights, humanitarian laws, and other areas of international crimes. For example, the International Criminal Tribunal for the Former Yugoslavia (ICTY), the International Criminal Tribunal for Rwanda (ICTR), the Special Court for Sierra Leone (SCSL), the Extraordinary Chambers in the Court of Cambodia (ECCC), the Special Tribunal for Lebanon (STL), and the International Crimes Tribunal of Bangladesh (ICTB $)^{140}$ are some of the examples of penalizing war criminals through the process of the rule of law. On top of these developments, the institutionalization of the International Criminal Court (ICC) marks a special place in the history of international law and international relations. However, many Asian countries like China, India, Indonesia, Nepal, Pakistan, and others are not parties to the ICC. Only eighteen countries have so far been parties to the ICC from Asia-Pacific

136. See Article 1.3 of the UN Charter, which states that the purposes of the United Nations are: "To achieve international cooperation in solving international problems of an economic, social, cultural, or humanitarian character, and in promoting and encouraging respect for human rights and for fundamental freedoms for all without distinction as to race, sex, language, or religion."

137. In the Lotus case, Ser. A, No. 10 (192), dissenting Judge Moore of the Permanent Court of International Justice stated that, “. . . in the case of what is known as piracy by law of nations, there has been conceded a universal jurisdiction, under which the person charged with the offence may be tried and punished by any nation into whose jurisdiction he may come..."

138. See Malcolm N. Shaw, International Law 619 (Cambridge University Press, 6th ed., 2008). Shaw writes, ". . . most of the agreements in the nineteenth century relating to the suppression of the slave trade provided that warships of the parties to the agreements could search and sometimes detain vessels suspected of being involved in the trade, where such vessels were flying the flags of the treaty states."

139. Id. at 397.

140. See OHCHR, Pillay Alarmed at Sentencing of 152 Paramilitary Personnel to Death in Bangladesh, (November 6, 2013), available at http://www.ohchr.org/EN/NewsEvents/Pages/ DisplayNews.aspx?NewsID=13953\&LangID=E . Pillay condemning the process of the ICTB said that, "The crimes committed during the mutiny were utterly reprehensible and heinous, and my sympathies are with the grieving families, but justice will not be achieved by conducting mass trials of hundreds of individuals, torturing suspects in custody and sentencing them to death after trials that failed to meet the most fundamental standards of due process." 
region. ${ }^{141}$ The United States also has not yet joined the ICC.

Irrespective of national boundaries and the position of a person, the ICC exercises jurisdiction over any person ${ }^{142}$ within the jurisdiction of its State Parties committing crimes prohibited by the ICC Statute (Rome Statute). ${ }^{143}$ The ICC exercises its jurisdiction over four specific cases, ${ }^{144}$ as follows:

- the crime of genocide,

- crimes against humanity,

- war crimes, and

- the crime of aggression.

But the ICC has its limitations. It only tries crimes committed after the ICC Statute came into force from July $1,2002 .{ }^{145}$ The ICC exercises its jurisdiction on the basis of the referral of the crime to it by three processes, as follows: ${ }^{146}$

- referred by State Parties to the Prosecutor of the ICC,

- referred to the Prosecutor of the ICC by the Security Council of the UN, and

- investigations started by the Prosecutor of the ICC on his/her own, based on information received.

The ICC has 121 States Parties. Out of them, 33 are African States, 18 are Asia-Pacific States, 18 are from Eastern Europe, 27 are from Latin American and Caribbean States, and 25 are from Western European and other States. ${ }^{147}$ Until, November 2013, 20 cases in 8 situations have been brought before the ICC. To date, four States Parties to the ICC: Uganda, the Democratic Republic of Congo, the Central African Republic, and Mali have been referred to the ICC regarding crimes that occurred on their territories. The Security Council of the UN has referred the cases of Sudan (Darfur), and Libya. Both of them are non-States Parties to the ICC, but the SC can refer such cases by exercising its power under

141. The 18 Asian-Pacific Countries as Parties to the ICC are: Afghanistan, Bangladesh, Cambodia, Cook Islands, Cyrus, Fiji, Japan, Maldives, Marshall Islands, Korea, Mongolia, Nauru, Philippines, Samoa, Tajikistan, Timor-Leste, \& Vanuatu.

142. See Article 1 of the ICC Statute. Article 4.2 of the ICC Statute provides that, "The Court may exercise its functions and powers, as provided in this Statute, on the territory of any State Party and, by special agreement, on the territory of any other State."

143. See Rome Statute of the International Criminal Court, done at Rome on 17 July 1998, come into force on 1 July 2002, available at http://www.icc-cpi.int/en_menus/icc/legal\%20 texts\%20and\%20tools/Pages/legal\%20tools.aspx .

144. See Articles 5-8bis of the ICC Statute.

145. See Article 11 of the ICC Statute.

146. See Articles 13-15 of the ICC Statute.

147. See ICC, the States Parties to the Rome Statute, visited on March 7, 2013; available at http://www2.icc-cpi.int/Menus/ASP/states+parties . 
Chapter VII of the UN Charter. The Prosecutor, with the authorization from the pre-trial Chambers of the ICC,. has initiated the investigation in the situation of Kenya, and Cote d'Ivoire. ${ }^{148}$ The first case decided by the ICC was the case of Thomas Lubanga Dyilo, who was found guilty on March 14, 2012, and has been sentenced for 14 years. He is currently in prison in The Hague. He was found guilty for war crimes, including the enlisting and conscription of children under the age of 15 years and using them to participate actively in hostilities. ${ }^{149}$ Similar cases of conscription of child in the insurgent armies by the Maoist in Nepal has been found, but Nepal not being a party to the ICC, no action against the perpetrator could be taken by the ICC, however, the application of Chapter VII process cannot be ignored.

With these developments, international relations can be perceived through the lenses of constitutionalism underpinned in international rules designed to deliver uniform standards for the harmonization of state behaviors. In short, it can be said that international rules bind actors and their behaviors in managing international relations. As observed by the Global Neighborhood Report, it can be concluded that the very essence of global governance is the capacity of the international community to ensure compliance with international rules, ${ }^{150}$ which has reinforced the positivity of global constitutionalism.

\section{Global Constitutionalism}

For Carr, international relations had to be a subject of political science that would bring the 'is' and 'ought' together. ${ }^{151}$ Carr's idea is comparable with the Hartian idea of the unity of primary and secondary rules. ${ }^{152}$ The system of anarchy envisioned by the realist school of international relations with the basic assumptions that truth statements are conditioned to power relations, that states

148. See ICC, Situations and Cases, available at http://www.icc-cpi.int/en_menus/icc/ situations\%20and\%20cases/Pages/situations\%20and\%20cases.aspx .

149. See ICC, the Prosecutor v. Thomas Lubanga Dyilo, available at http://www.icc-cpi.int/en_ menus/icc/situations $\% 20$ and $\% 20$ cases/situations/situation $\% 20$ icc $\% 200104 /$ related\%20cases/ icc\%200104\%200106/Pages/democratic\%20republic\%20of\%20the\%20congo.aspx .

150. See Our Global Neighborhood: Report of the Commission on Global Governance, Chapter 6 (Oxford University Press, 1995).

151. See Christian Reus-Smit \& Duncan Snidal, Between Utopia and Reality: The Practical Discourses of International Relations, in The Oxford Handbook of International Relations 7 (Christian Reus-Smit \& Duncan Snidal eds., Oxford University Press, 2010).

152. See H. L. A. Hart, the Concept of Law Chapter V (Clarendon Press, 2nd ed., 1994). 
are the only actors of international relations, and anarchy is the only reality of the international behaviors continuously rejected the need for transforming the 'ought' into 'is' domain. However, the realist resistance has undergone a sea of change since the emergence of the idea of global governance: the institutionalization of legalism, and global constitutionalism. Against the changing context of international relations, Hans Morgenthau also admitted that international law in most instances had been scrupulously observed. ${ }^{153}$

In recent days, much research in international relations has been founded on a positivist conception of social knowledge. Positivists generally gravitate toward a view of social inquiry in which patterns of human behavior are presumed to reflect objective principles, laws, or regularities that exist above and beyond the subjective orientations of actors and scholars. ${ }^{154}$ The positivist idea has also been proven with the shifting nature of international law from merely a law of morality to a law with all basic characteristics of a positivist structure: legitimacy, validity, and enforceability. Against this background, the Global Neighborhood Report claims that the standing of international law is now unquestioned. Certainly states are sovereign; though, they are not free to do whatever they wish. Just like local laws, international rules constrain the unrestrained actions of sovereign states. ${ }^{155}$ Indeed, international laws not only constrain states, but also empower them. With the development of the rules-based international system, the weaker and poorer countries are much more secured with their enhanced global standing than ever before. Certainly, the small and marginalized Asian states are the beneficiary of this system of global constitutionalism.

The English School's idea about world society ${ }^{156}$ and the constructivist idea about legitimacy ${ }^{157}$ have necessarily elucidated the rationality of international

153. Cited in Beth Simmons, International Law and International Relations, in THE OxFORD Handbook of Law and Politics Chapter 11 (Keith E. Whittington, R. Daniel Kelemen, \& Gregory A. Caldeira eds., Oxford University Press, 2008).

154. See Peter Katzenstein \& Rudra Sil, Eclectic Theorizing in the Study and Practice of International Relationss, in The OxFoRd HANDBook of INTERNATIONAL RELATIONs 111 (Christian Reus-Smit \& Duncan Snidal eds., Oxford University Press, 2010).

155. See Our Global Neighborhood: Report of the Commission on Global Governance, Chapter 6 (Oxford University Press, 1995).

156. See Tim Dunne, The English School, in The Oxford Handbook of International Relations 270-279 (Christian Reus-Smit \& Duncan Snidal eds., Oxford University Press, 2010). For detail discussion on the English School, see Hedley Bull, The Anarchical Society: A Study of Order IN World Politics (Columbia University Press, 1995).

157. For detail discussion see Beth Simmons, International Law and International Relations, in the Oxford Handbook of Law and Politics Chapter 11 (Keith E. Whittington, R. Daniel 
relations projected under international law. The concept of global governance expressed through legalism or global constitutionalism requires states to comply with the entrenched international rules. The entrenchment further strengthened by a number of mechanisms including policy review, and settlements of disputes has logically heightened the authority of international law. For example, Article 40 of the ICCPR requires State Parties to submit reports on the measures taken by them in regard to giving effect to the rights recognized by the ICCPR. The Human Rights Committee reviews the reports and makes appropriate comments. It is not only the Committee but also any State Party that can ask another State Party to provide an explanation on the implementation of the ICCPR. Each sovereign state is legally required to provide an explanation of its human rights commitments and situations to another sovereign state, if inquired. ${ }^{158}$

The concept of global constitutionalism consolidated by the idea of legalism is succinctly manifested in the system of global governance under the World Trade Organization (WTO). A few examples in this regard elucidate the legalistic manifestation. China adopts a policy that administers export quotas, imposes export duties, designs minimum export price requirements, and demands export licensing systems to be in place, among other requirements, on rare earths, tungsten and molybdenum. The US, EU, and Japan considered that the domestic policy of China distorts global market by creating competitive advantages in favor of China's domestic industries to the detriment of foreign competitors. In nontechnical terms, it poses a question of whether a country is free to decide how much of its natural resources should be exported. The US, EU, and Japan argue that the Chinese export restriction policy violates WTO rules; the dispute is now sub-judiced before the WTO Dispute Settlement Panel. ${ }^{159}$ Whatever decision may

Kelemen, \& Gregory A. Caldeira eds., Oxford University Press, 2008); see also Stefano Guzzini and Anna Leander, Constructivism and International Relations: Alexander Wendt and his Critics (Routledge, 2005); Catherine Twomey Fosnot ed., Constructivism: Theory, Perspectives and Practice (Teachers College press, 2nd ed., 2005).

158. See Article 41 (a) of the International Covenant on Civil and Political Rights, 1966, which provides that, "If a State Party to the present Covenant considers that another State Party is not giving effect to the provisions of the present Covenant, it may, by written communication, bring the matter to the attention of that State Party. Within three months after the receipt of the communication, the receiving State shall afford the State which sent the communication an explanation or any other statement in writing clarifying the matter, which should include, to the extent possible and pertinent, reference to domestic procedures and remedies taken, pending, or available in the matter."

159. See China-Measures Related to the Exportation of Rare Earths, Tungsten and Molybdenum, DS431/DS432/DS/433, (September 2012), available at http://www.wto.org/english/tratop_e/dispu_e/ dispu_status_e.htm. 
come out, the point is that international bodies can review domestic policies, and test whether they are consistent with the international rules.

A domestic law, the US Clean Air Act, 1990 amendment, recognized two different standards of gasoline refinement for domestic refiners and foreign refiners. The law offered a lower level of standards to the domestic refiners and required higher level of standards to the foreign refiners. Venezuela, whose gasoline exports to the US constitute an important segment of its economy, was affected by the US law. Venezuela challenged the US law and practices before the WTO Dispute Settlement Body, calling them discriminatory and inconsistent with WTO rules. In its first decision, the Appellate Body of the WTO declared that Section 211(k) of the US Clean Air Act violated the WTO rules. ${ }^{160}$ The WTO required the US to make the Clean Air Act compatible with the WTO rules. The US, for first time in its history, amended its laws as directed by an international agency. ${ }^{161}$

The Indian Patent Act did not provide a system of patent protection for pharmaceutical and agricultural chemical products. It also lacked a formal system of permitting the filing of patent applications for pharmaceutical and agricultural chemical products. It also did not provide exclusive marketing rights for such products. The US considered the Indian patent regime inconsistent with the WTO rules and asked the WTO Dispute Settlement Body to rule on the issue requiring India to make its patent regime compatible with the WTO. The Appellate Body recommended that the Dispute Settlement Body request India to bring its domestic legal regime for patent protection of pharmaceutical and agricultural chemical products into conformity with India's obligations under Articles 70.8 and 70.9 of the TRIPS Agreement. ${ }^{162}$ India subsequently changed its domestic laws relating to patent regime in order to comply with the WTO decision. ${ }^{163}$

The EC prohibited importation of beef products containing artificial hormones

160. See Appellate Body, United States - Standards for Reformulated and Conventional Gasoline, WT/DS2/AB/R (April 29, 1996), available at http://www.wto.org/english/tratop_e/dispu_ e/cases_e/ds2_e.htm.

161. See WTO, Venezuela, Brazil versus US: Gasoline, available at https://www.wto.org/english/ tratop_e/envir_e/edis07_e.htm. The United States had agreed with Venezuela that it would amend its regulation within 15 months, and on 26 August 1997 it had reported to the Dispute Settlement Body that a new regulation had been signed on 19 August 1997.

162. See Appellate Body, India - Patent Protection for Pharmaceutical and Agricultural Chemical Products, WT/DS50/AB/R (Dec. 19, 1997), available at http://www.wto.org/english/tratop_e/dispu_e/ cases_e/ds50_e.htm.

163. See WTO, Implementation Notified by Respondent, (April 28, 1999), available at http:// www.wto.org/english/tratop_e/dispu_e/cases_e/ds50_e.htm. 
from the US on the ground of public policy and safety under various EC directives. This case is also known as the Hormone Dispute or Mad Cow disease case. The EC prohibited importation of beef products from many countries outside Europe including from Australia, Canada, and the US. The major argument of the EC was that the meat products from those countries were potentially harmful for human health. The EC had imposed import restrictions on the basis of precautionary principles. The US, Canada, Australia, and other countries argued that the EC's suspicion was not based on scientific evidence. The major dispute was over the issue of whether the EC could impose trade restrictions on the basis of public policy and political understanding. The Appellate Body found that the EC directives were not consistent with the Sanitary and Phytosanitary Agreement (SPS) of the WTO and thus asked the Dispute Settlement Body to request the EC to bring its directives to be compatible with the SPS Agreement. ${ }^{164}$ The EC did not comply with the WTO decision on time. The US asked the WTO to authorize sanctions against the EC. On 26 July 1999, the WTO authorized sanctions against the EC of the amount equivalent to the loss suffered by the US, being $\$ 116.8$ million. ${ }^{165}$

The above-mentioned examples elucidate the nature of global constitutionalism. In other words, domestic laws, policies, and practices are required to be compatible with international laws. International laws assume the position of supremacy like a constitution. State Parties bear an obligation to ensure that their domestic laws and policies give effect to international rules. Paulus writes that in the same vein in which a constitution unifies the domestic polity in one legal superstructure, a developed institutional reading of international law would unify the international community in a single coherent constitutional structure. ${ }^{166}$ Trachman observes that the international legal system indeed has a constitution, with enabling, constraining, and supplemental features. He further claims that there is also no doubt that the WTO constitution is a part of this broader constitution. ${ }^{167}$

164. See Appellate Body, EC Measures Concerning Meat and Meat Products (Hormones), WT/ DS26/AB/R, WT/DS48/AB/R (Jan. 16, 1998), available at http://www.wto.org/english/tratop_e/ dispu_e/cases_e/ds26_e.htm .

165. See WTO, EC Measures Concerning Meat and Meat Products (Hormones), WT/DS26/AB/ R, WT/DS48/AB/R (Sept. 25, 20009), available at http://www.wto.org/english/tratop_e/dispu_e/ cases_e/ds26_e.htm .

166. See Andreas L. Paulus, The International Legal System as a Constitution, in Ruling the World? Constitutionalism, International Law, and Global Governance 69 (Jeffrey L. Dunoff \& Joel P. Trachtman eds., Cambridge University Press, 2009).

167. See Joel P. Trachman, Constitutional Economics of the World Trade Organization, in RuLING 
These examples also elucidate the legalistic framework of international rules. For example, WTO trade negotiations carry out three activities: they formulate new rules, amend existing rules, and instruct WTO Members to change their domestic laws, policies, and administrative mechanisms. The conclusion of the trade negotiations agreed by Members will come into force through the regular treaty-making process, which reflects the legislative process. In addition, laws are also made through an interpretative adjudicatory mechanism under the Dispute Settlement Body (DSB). The DSB adopts the decisions of the Appellate Body and Panels that establish a body of jurisprudence practically, which is different from legislation in the sense that it is the adjudicatory process, which interprets rules and reviews the compatibility of domestic laws and policies. Along with these legislative and adjudicatory processes, the WTO also has a powerful enforcement system. These developments are not unique to the WTO alone; today these are common in international legal regimes, nevertheless, the WTO framework of constitutionalization is one of the most accomplished one that we have today.

Law as a science is all about the explication of the nature of a legal concept. By the same token, this is also true in the arena of international law. International law is shaped at an unprecedented level in reaction to the globalization of legal concepts. As one of the most catalytic processes of today's international relations, international law is profoundly transforming international relations from a simple diplomatic form to a structure, which is based on rules. These rules at the global level are institutionalizing a system of global governance. The nature of this system of global governance is fundamentally designed by the very concept of global constitutionalism. Making rules at the global level is therefore profoundly important, as it demands states to regulate their relations and provide necessary institutions, including laws, for the effective cooperation in the global system. As a result, the demand for law as an ordering structure of globalization is progressively institutionalizing a global legal system. ${ }^{168}$

\section{Conclusion}

In Dunoff and Pollack's account, the detachment between international relations (IR) and international law (IL) had been stretched wide apart, even after the Second World War when political scientists, predominately realists, rejected

the World? Constitutionalism, International Law, and Global Governance 228 (Jeffrey L. Dunoff \& Joel P. Trachtman eds., Cambridge University Press, 2009).

168. See BHANDARI, supra note. 
the notion that international law could serve as a meaningful constrain on states' pursuit of national interests. ${ }^{169}$ However, the fact that after the establishment of the United Nations (UN), states have concluded over 180,000 treaties and related subsequent actions, which have been published in the UN Treaty Series of over 2,600 volumes. Also, during the period of the League of Nations, a number of treaties were concluded and published in 205 volumes of the League of Nations Treaty Series. ${ }^{170}$ These facts demonstrate that states were continuously engaged in designing international relations with the mechanisms of international law despite the reluctance of the realists. Consequently, international law has been evolving as a thoughtful apparatus for managing international relations. In this context, we could agree with Justice Owada that Asia, being one of the most important and vibrant regions of the world in international affairs, is gaining an active and influential role in the realm of international relations. ${ }^{171}$

Some observers view that nation-states have remained preeminent until the current era of globalization, a time when global flows began to undermine the nation-state. ${ }^{172}$ Ohame contends that, in terms of the global economy, nation-states have become little more than bit actors. ${ }^{173}$ Khan radically observes that due to increased interdependence among the peoples of the world, the nation-state has become dysfunctional in serving the needs of global life. ${ }^{174}$ Perhaps, some may find these observations as slight overstatements. Nevertheless, the recent developments have signified the governing role of international law in managing international relations and defining the nature of constitutionalism as the impetus of global governance. In this regime of global governance, the relationship between IR and IL has become more welcoming and symbiotic than ever before. ${ }^{175}$

169. See Jeffrey L. Dunoff and Mark A. Pollack, International Law and International Relations: Introducing an Interdisciplinary Dialogue, in Interdisciplinary Perspectives on International Law and International Relations

170. See UN, United Nations Treaty Collection, available at http://treaties.un.org/Pages/ Overview.aspx?path=overview/overview/page1_en.xml .

171. See Hisashi Owada, Asia and International Law, 1 Asian Journal of International Law 3, 3-11 (2011).

172. See George Ritzer, Globalization the Essentials Kindle Location 3172 (Wiley-Blackwell, 2011).

173. Cited in George Ritzer, Globalization the Essentials Kindle Location 3197 (Wiley-Blackwell, 2011); see also Kenichi Ohmae, The End of the Nation-State: The Rise of Regional Economies (Free Press).

174. See generally L. Ali Khan, The Extinction of Nation-States: A World Without Borders (Kluwer Law International 2011).

175. See Anne-Marie Slaughter, Andrew S. Tulumello, \& Stepan Wood, International Law and 
Welcoming international law as the governing apparatus of global constitutionalism, this paper appreciates the instrumental role of international law in managing international relations. Some of the major findings and conclusions of this paper can be stated as follows:

- First, through a domestic legal process, the rules of international law are being transformed into domestic legal systems in enhancing the harmonization between domestic and international laws. In this course, either necessary laws are enacted to give effect to international laws or international laws are contemplated as a part of the domestic legal system.

- Second, international judicial decisions inspire necessary changes and reform in domestic legal systems through reviewing the compatibility of domestic laws and policies with international laws.

- Third, through international negotiations, international laws also embody legal concepts and practices grown in different legal systems, implying a truly global nature of international rules, which is reflexive of the global legislative process. Though, due to the widespread continuation of biases and asymmetries in negotiations, especially in transmuting concepts into rules, the legitimacy of rules have often been called into questions.

- Fourth, the growing compliance and implementation of bilateral, regional, and multilateral agreements evidence constitutionalism as the touchstone of global governance.

- Fifth, with the emergence of global constitutionalism, domestic laws, policies, and administrative practices are demanded to be compatible with international laws. International laws are progressively assuming the position of supremacy over domestic laws like a constitution. State Parties are not free to eschew their obligations from giving effect to international laws. These minimum obligations of harmonization, supremacy, and authority of international law have shaped the process of constitutionalizing international law, which has already garnered the requisite legitimacy. In

\footnotetext{
International Relations Theory: A New Generation of Interdisciplinary Scholarship, 92 American Journal of International law 367-397, 393 (1998). They observe that, "IR and IL have rediscovered one another. A new generation of interdisciplinary scholarship has emerged, acknowledging that the disciplines represent different faces of and perspective on the same empirical and/or inter-subjective phenomena. Outsiders might categorize them as dividing the study of the international system in terms of positive versus normative, politics versus law. Insiders in both disciplines reject such facile distinctions. The reasons for the periodic divergence and reconvergence of the two fields have had more to do with the internalization of external events such as the Cold War and its end and the externalization of the internal dynamics of theory building and purported paradigm shifting."
} 
this regard, one of the obligations as well as contributions of Asia in constitutionalizing international relations can be attributed to its participation in strengthening the practice of global constitutionalism.

Against this background, this paper has gauged the constitutionalization of international relations as a metamorphic process in buttressing a trans-boundary transformation of legal concepts. Managing the possible modes and results of such a metamorphic process is at the forefront of the socio-economic, political, and legal discourse in Asia too. The opportunities can be found when there are harmonious, predictable and objective legal standards across the globe enabling an environment for international relations, especially in the field of international business, trade, and human rights, among others. The challenges are impregnably coupled with the internal resistance from countries to the gradually diminishing role of the traditional concept of sovereignty. The challenges are further aggravated with a lack of the capacity to implement the one-size-fits-all international standards at the domestic level.

Also, global governance ${ }^{176}$ is not a substitute for the nation-state. In fact, with the advent of global constitutionalism, nation-states are not only constrained, but also empowered and facilitated. As suggested by Whitman ${ }^{177}$ and Ritzer, ${ }^{178}$ this paper endorses the concept of governance in three different levels. First, local communities in support of civil society organizations and other community groups manage a number of local issues without the direct involvement of government, which can be called governance without government. Second, many actors like multinational corporations, business entities, the private sector, civil society organizations, academia, journalists, and other stakeholders engage in public policy issues without direct control and involvement of government, which can be stated governance through various public policy networks. Third, globalization institutionalized through international rules and institutions, which is reflexive of governance at the global level. In fact, unlike the claim of Ritzer that these three

176. Rosenau contends that there is a difference between governance of the world and governance in the world. The term 'global governance' does not necessarily refer to a central authority. Rather, global governance is a lot of governmental and nongovernmental activities that occur in local places, the results of which contribute to the overall order of world affairs. Cited in Jim Whitman, Global Dynamics and the Limits of Global Governance, 17 GLOBAL SocieTy 253-272, 253 (2003).

177. See Jim Whitman, Global Dynamics and the Limits of Global Governance, 17 GLoBAL SocieTY 253-272 (2003).

178. See George Ritzer, Globalization the Essentials Kindle Location 3464 (Wiley-Blackwell, 2011); see also Kenichi Ohmae, The End of the Nation-State: The Rise of Regional Economies (Free Press, 1996). 
forms of governance have caused the decline of the nation-state; ${ }^{179}$ as discussed above this paper contends that with these developments sovereign integrity of countries has been further strengthened, domination and unruly behaviors of powerful countries has been largely contained, and uniform standards of international cooperation have been institutionalized, which indeed strengthen the sovereignty of nation-states. For the overall growth of Asia, these developments seem more soothing and advantageous.

William James once told that, “. . . the course of history is nothing but the story of men's struggle from generation to generation to find a more inclusive order." ${ }^{180}$ In this light, global constitutionalism may be taken as the apogees or culminations of international relations resulting from trans-border human efforts. The rapid changes occurring in the international legal order highlight a movement away from the old juristic approach. The issues that we used to traditionally consider the exclusive matter of the domestic jurisdiction of a state, some of them have already converged into the global or multilateral domain. It has become possible because the process of multilateralism is chipping away at the parochial ideology of territorialism. Though, it is true that this optimism might take a long time to be an unflinchingly acceptable universal standard.

Jurgen Habermas ${ }^{181}$ argues for supra-national capacity in managing the framework of globalization. This supra-national capacity requires juristic support in identifying legal concepts suitable for and complementary to constitutionalism. It encourages the analysis of the future of law in the era of globalization. William Twining, responding to the scope, depth, and range of transformation of law and legal concepts by globalization, calls for a thorough rethinking of the process. Twining believes that constitutionalization offers fundamental challenges to the

\section{Id.}

180. See Roscoe Pound, Preface, quoted in Eugene G. Gerhart, American Liberty \& Natural Law 3 (Boston, The Beacon Press 1953).

181. See Herbert Dittgen, World Without Borders? Reflections on the Future of the NationState, 34 Government \& OpPosition 2, quoted at 166 (1999). The passage reads, "The nation-state once provided a convincing response to the historic challenge to provide in the process of dissolution of a functional equivalent to pre-modern forms of social integration. Today, we are faced with an analogous challenge. The globalization of economic production and it's financing of technology and arms transfers, and particularly of ecological and military risks confronts us with problems which cannot be solved within the framework of the nation-state or by the usual kind of agreements between sovereign states. If the signs are not deceiving the nation-state's sovereignty will continue to be undermined, and the supra-national capacity for political action must be developed and consolidated." 
Global Constitutionalism and the Constitutionalization of International Relations: A Reflection of Asian Approaches to International Law

contemporary legal theory and thinking. ${ }^{182}$

In conclusion, in the $20^{\text {th }}$ century and previous eras, the issue of governance had exclusively fitted into the jurisdiction of domestic regime but excluding the substantial participation of people in the process of governance. With the growth of the idea of constitutionalization of international law, the participation of people both at local and international policy making processes has been significantly enhanced. In short, constitutionalization of international law is considerably changing the pattern of international relations and cooperation among sovereign states, as envisaged by Woodrow Wilson; the jungle of international politics would turn into a zoo by the system of the rule of law. ${ }^{183}$ The growing process and effects of constitutionalism will not only demand the international actors to be responsible but also respect the supremacy of international law, which is correspondingly applicable and suitable to shape the Asian approach to international law. Despite diversity, in all its likelihood, Asia seems to be gradually advancing its role from a bystander to the partner of global constitutionalism, in terms of transmuting concepts into international rules, harmonizing them at the domestic level, and implementing them in practice. This approach seems expedient in enabling Asia to redeem its active partnership and responsibility in the process of constitutionalizing international relations and upkeep its constructive engagement in transforming the international system from anarchy to constitutionalized order.

182. See generally William Twining, General Jurisprudence: Understanding Law from a Global Perspective (Cambridge University Press, 2009); see also William Twining, Globalization and Legal Theory (Northwestern University Press, 2001).

183. See Andrew Heywood, Global Politics 65 (Palgrave Macmillan, 2011). 
